\title{
Sea level dynamics and coastal erosion in the Baltic Sea region
}

\author{
Ralf Weisse $^{1}$, Inga Dailidienè ${ }^{2}$, Birgit Hünicke ${ }^{1}$, Kimmo Kahma $^{3}$, Kristine Madsen $^{4}$, Anders Omstedt ${ }^{5}$, \\ Kevin Parnell ${ }^{6}$, Tilo Schöne ${ }^{7}$, Tarmo Soomere ${ }^{6}$, Wenyan Zhang ${ }^{1}$, and Eduardo Zorita ${ }^{1}$ \\ ${ }^{1}$ Institute of Coastal System Analysis and Modeling, Helmholtz Zentrum Hereon, 21502 Geesthacht, Germany \\ ${ }^{2}$ Klaipeda University, Marine Research Institute, Klaipeda 92294, Lithuania \\ ${ }^{3}$ Finnish Meteorological Institute, 00560 Helsinki, Finland \\ ${ }^{4}$ Danish Meteorological Institute, 2100 Copenhagen, Denmark \\ ${ }^{5}$ University of Gothenburg, Department of Marine Sciences, 40530 Gothenburg, Sweden \\ ${ }^{6}$ Tallinn University of Technology, School of Science, Department of Cybernetics, 12618 Tallinn, Estonia \\ ${ }^{7}$ German Research Centre for Geosciences GFZ, 14473 Potsdam, Germany
}

Correspondence: Ralf Weisse (ralf.weisse@hereon.de)

Received: 19 February 2021 - Discussion started: 25 February 2021

Revised: 29 June 2021 - Accepted: 7 July 2021 - Published: 17 August 2021

\begin{abstract}
There are a large number of geophysical processes affecting sea level dynamics and coastal erosion in the Baltic Sea region. These processes operate on a large range of spatial and temporal scales and are observed in many other coastal regions worldwide. This, along with the outstanding number of long data records, makes the Baltic Sea a unique laboratory for advancing our knowledge on interactions between processes steering sea level and erosion in a climate change context. Processes contributing to sea level dynamics and coastal erosion in the Baltic Sea include the still ongoing viscoelastic response of the Earth to the last deglaciation, contributions from global and North Atlantic mean sea level changes, or contributions from wind waves affecting erosion and sediment transport along the subsiding southern Baltic Sea coast. Other examples are storm surges, seiches, or meteotsunamis which primarily contribute to sea level extremes. Such processes have undergone considerable variation and change in the past. For example, over approximately the past 50 years, the Baltic absolute (geocentric) mean sea level has risen at a rate slightly larger than the global average. In the northern parts of the Baltic Sea, due to vertical land movements, relative mean sea level has decreased. Sea level extremes are strongly linked to variability and changes in large-scale atmospheric circulation. The patterns and mechanisms contributing to erosion and accretion strongly depend on hydrodynamic conditions and their variability. For large parts of the sedimentary shores of the Baltic Sea, the wave climate and the angle at which the waves approach the nearshore region are the dominant factors, and coastline changes are highly sensitive to even small variations in these driving forces. Consequently, processes contributing to Baltic sea level dynamics and coastline change are expected to vary and to change in the future, leaving their imprint on future Baltic sea level and coastline change and variability. Because of the large number of contributing processes, their relevance for understanding global figures, and the outstanding data availability, global sea level research and research on coastline changes may greatly benefit from research undertaken in the Baltic Sea.
\end{abstract}




\section{Introduction}

Regional climate change in the Baltic Sea basin has been systematically assessed in two comprehensive assessment reports initiated by the Baltic Sea Experiment (BALTEX) and its successor Baltic Earth (https://baltic.earth, last access: 13 August 2021): BACC I (BACC Author Team, 2008) and BACC II (BACC II Author Team, 2015). As a follow-up, the present study represents one of the thematic Baltic Earth Assessment Reports (BEAR) which consist of a series of review papers summarizing and updating the knowledge around the major Baltic Earth science topics. As part of the series, this study concentrates on sea level dynamics and coastal erosion in the Baltic Sea region.

The Baltic Sea is an intracontinental, semi-enclosed sea in northern Europe that is connected to the Atlantic Ocean via the narrow and shallow Danish straits (see Fig. 1). With an area of about $417000 \mathrm{~km}^{2}$ and a volume of about $21200 \mathrm{~km}^{3}$ (Jakobsson et al., 2019), it contributes less than $\frac{1}{10}$ of a percent to the area and the volume of the global ocean (Eakins and Sharman, 2010). For this reason, contributions from the Baltic Sea to global sea level changes are small. Over the last centuries and decades, sea level and coastline changes in the Baltic Sea have, nevertheless, received considerable research attention. The reasons for this are as follows:

1. Historically, changes in sea level and in coastlines have influenced Baltic Sea harbors, settlements, and economic activity over millennia. As a result, the area comprises not only some of the longest available tide-gauge records worldwide but also much longer observational evidence. This information has challenged our understanding of sea level dynamics and land movements associated with the glacial isostatic adjustment (GIA) (e.g., BIFROST project members, 1996) and has also contributed significantly to our present understanding of large-scale sea level changes on a global scale.

2. Processes and forcing contributing to Baltic sea level dynamics and coastline change vary substantially over short distances (Harff et al., 2017). For example, there is a pronounced north-south gradient in GIA leading to substantial differences in the rates of relative sea level change across the Baltic Sea (see below). In combination with zonal and meridional changes in the geological composition of the coast and the variability of the wind- and wave-driven hydrodynamics, this leads to variations in the relative contributions of these factors to erosion and sedimentation in the order of kilometers. Timescales of processes and forcings also vary considerably, ranging from a few seconds (e.g., wind waves) to millennia (e.g., GIA). Again, this enables researchers to study a wide range of phenomena with larger and global relevance (e.g., glacial isostasy or characteristics of relative sea level changes).
3. Finally, from a regional perspective, regional mean and extreme sea level changes and erosion represent important indicators of regional climate variability and change. Any long-term change in mean or extreme sea levels as well as in erosion and accretion will have an immediate impact on society, influencing sectors such as coastal protection, shipping, or development of offshore renewable energy resources, among others (e.g., Weisse et al., 2015).

Historically, considerable progress in sea level research worldwide was made based on early Baltic Sea observations which indicated that sea levels were falling. Stones carved with runic texts, linking them to the coast, were found quite a distance from the present-day coastline. Shallow harbors were gradually abandoned as the water level apparently declined. In the 18th century, Celsius (1743) estimated the rate of falling water levels based on so-called seal rocks (Fig. 2a). Seal rocks were economically important for seal hunting and are, therefore, well-described in the written records (Ekman, 2016).

The reason for the sinking water levels was unclear and was debated until it was understood that thick layers of ice had covered Scandinavia in the past and that sea levels were not falling but instead the land was rising elastically after the ice cover disappeared. The idea of postglacial uplift was proposed in the mid-19th century by Jamieson (1865) and then later by others, although the causes of the uplift were strongly debated. Further major progression with respect to this idea was not possible until new knowledge of the thermal history of the Earth due to changes in Sun-Earth orbital motions was available in the late 19th century and early 20th century (Milanković, 1920).

Figure $2 b$ shows observed Baltic sea level change and land rise for Stockholm, one of the longest available tide-gauge records comprising almost 250 years of measurements. Apart from the long-term trend, substantial variability on different timescales is inferred. A sketch illustrating processes contributing to such variability is shown in Fig. 3. As for any semi-enclosed basin, such processes can be separated into processes that alter the volume of the Baltic Sea and/or the total amount of water in the basin, and processes that redistribute water within the Baltic Sea (Samuelsson and Stigebrandt, 1996; Svansson, 1980). From analyses of tide-gauge data and dynamical consideration, we know that processes with characteristic timescales of about half a month or longer can change the volume of the water in the Baltic Sea. Due to the limited transport capacity across the Danish straits, processes with shorter timescales primarily redistribute water within the Baltic Sea (Johansson, 2014; Soomere et al., 2015; Männikus et al., 2019). At longer timescales, North Atlantic mean sea level changes and effects from large-scale atmospheric variability have the strongest influence on Baltic mean sea level variability and change apart from changes caused by movements in the Earth's crust due to GIA. For 


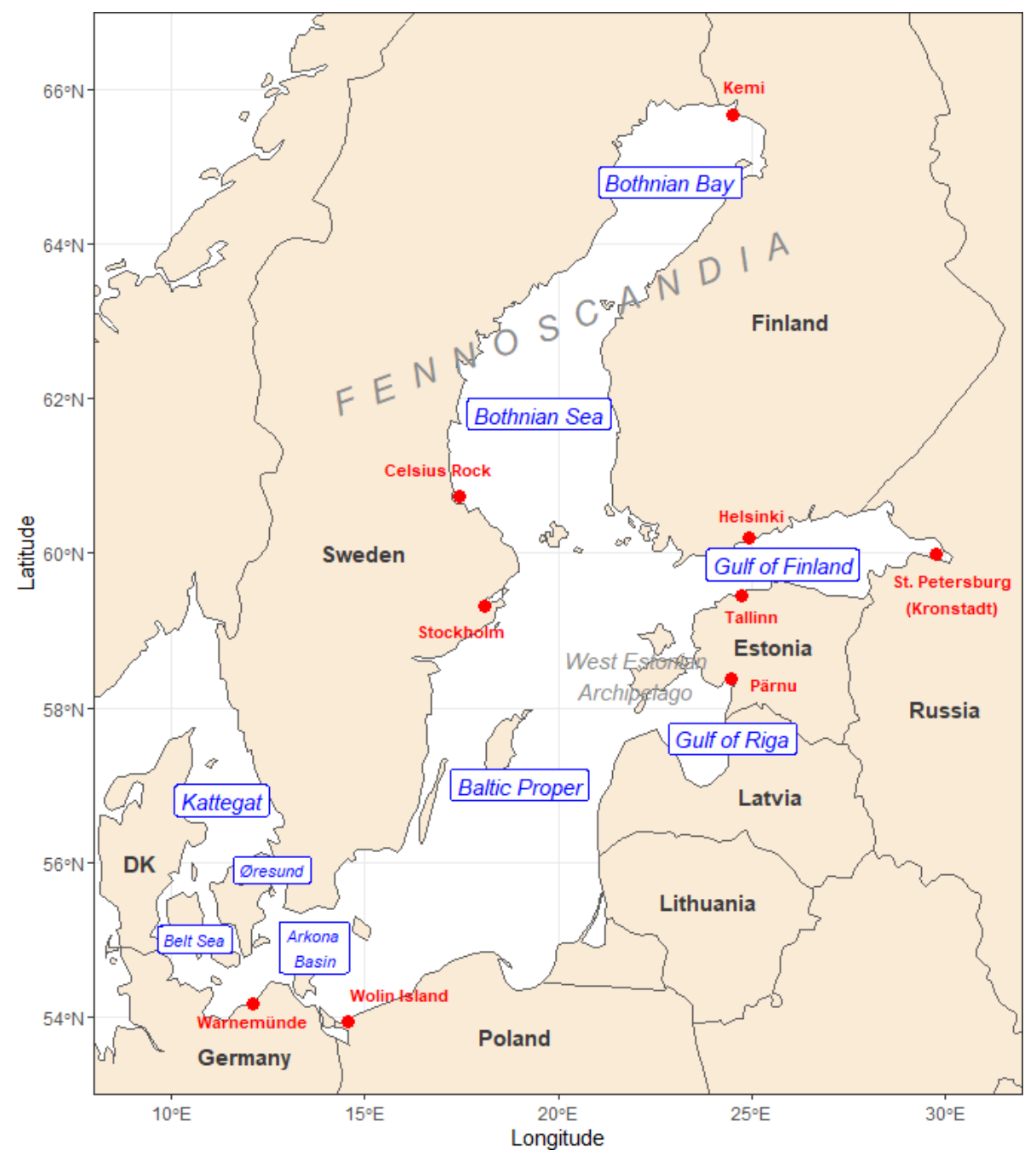

Figure 1. Map of the Baltic Sea, including the geographical names used in this paper. The Sound (Øresund) and the Belt Sea form the Danish straits. Bothnian Bay and the Bothnian Sea form the Gulf of Bothnia.

example, using experiments with a hydrodynamic model, Gräwe et al. (2019) showed that about $75 \%$ of the basinaveraged mean sea level change during the 1980-2000 period externally entered the Baltic Sea as a mass signal from the adjacent North Sea, whereas the remainder was caused by above-average zonal wind speeds during that period (Gräwe et al., 2019). Variations in the freshwater budget, precipitation minus evaporation $(P-E)$ and river runoff, can further contribute to seasonal and interannual sea level variations in the Baltic Sea in the order of centimeters to decimeters (Johansson, 2016; Hünicke and Zorita, 2006). Long-term average runoff exceeds $P-E$ by about a factor of 10 (Leppäranta and Myrberg, 2009). However, currently, no long-term trends in the freshwater budget are observed (Johansson, 2016; Rutgersson et al., 2014) that would add to presently observed rates of Baltic sea level change. On shorter timescales, processes such as changing wind regimes and atmospheric pressure patterns are the primary processes redistributing wa- ter masses within the Baltic Sea and are responsible for sea level variations occurring within the Baltic Sea (Hünicke and Zorita, 2006) and its semi-enclosed subbasins (Männikus et al., 2019). Other processes such as seiches or wind waves impact the height of the sea surface on very short timescales ranging from seconds to hours.

Sea level primarily controls the position of the shoreline (Harff et al., 2017). Much of the Baltic Sea shoreline (particularly in Finland and Sweden) is rock or consolidated sediments, which typically change over decades to millennia. Shorelines composed of unconsolidated sediments typically erode when sea level rises and accrete when sea level falls. However, several other factors modify the control that sea level exerts. Sediment availability and supply are fundamental. A useful conceptual model is the coastal sediment budget, with sediment transport being considered within sediment compartments, which essentially operate independently, particularly with respect to alongshore sedi- 

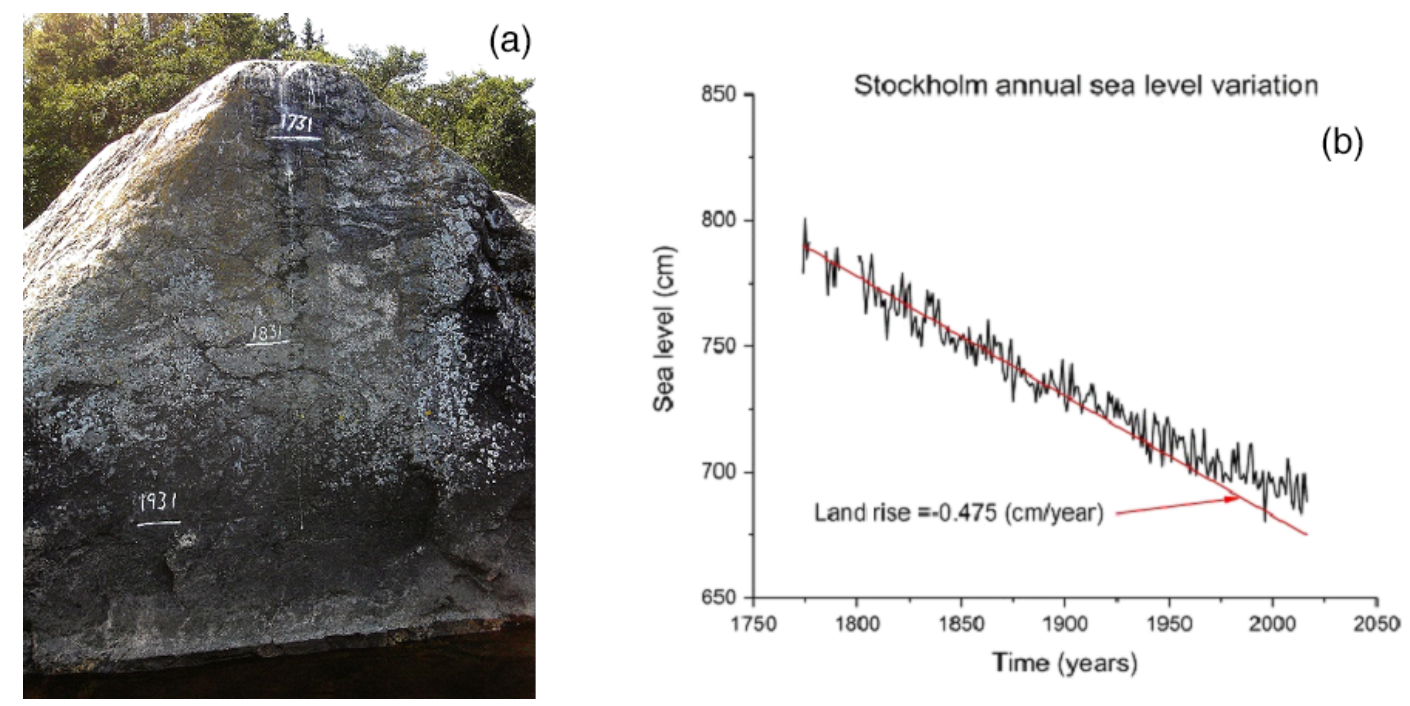

Figure 2. (a) The Celsius seal rock at Lövgrunden outside the Swedish city of Gävle on the Bothnian Sea coast (Ekman, 2016). The presentday water level is about $2 \mathrm{~m}$ below the 1731 mark (photo courtesy of Martin Ekman). (b) Stockholm annual sea level variations (black) and land rise (red) according to Ekman (2003) (redrawn from Omstedt, 2015).

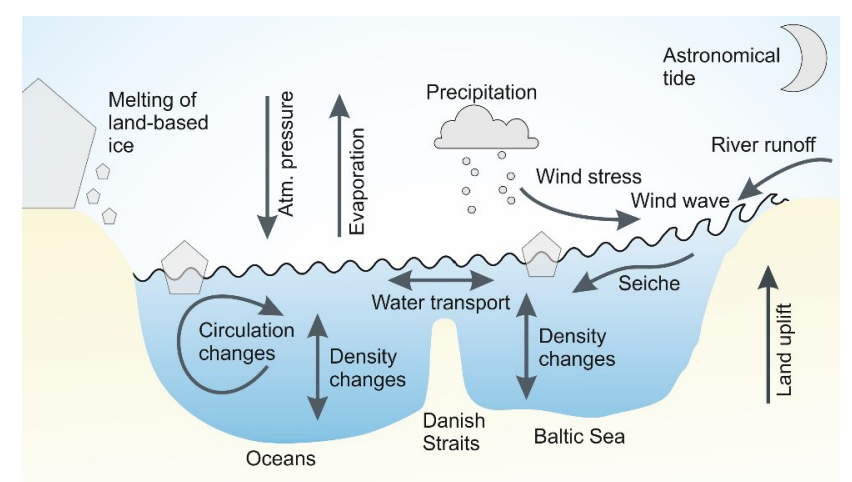

Figure 3. Processes contributing to sea level variability and change in the Baltic Sea (redrawn and modified from Johansson, 2014).

ment transport. Sediment compartments can be very small (hundreds of meters of shoreline) but can also range up to hundreds of kilometers. Where the sediment budget is in deficit, erosion occurs; where it is in surplus, the shoreline accretes. Overlying any long-term trend are shorter-term changes in the shoreline. Changes that occur after a storm event are typically called erosion, although technically if the sediment remains in the active sediment compartment, the use of the term "erosion" in this context may be seen as inaccurate. The Baltic Sea differs from many other coastal locations. For example, short wind fetches mean that swell waves are generally insignificant (Broman et al., 2006; Soomere et al., 2012), and waves often approach the shoreline at a large angle (Soomere and Viška, 2014). This means that the Baltic Sea shorelines are very sensitive to wind direction. Wave periods are short, leading to situations where waves can ap-

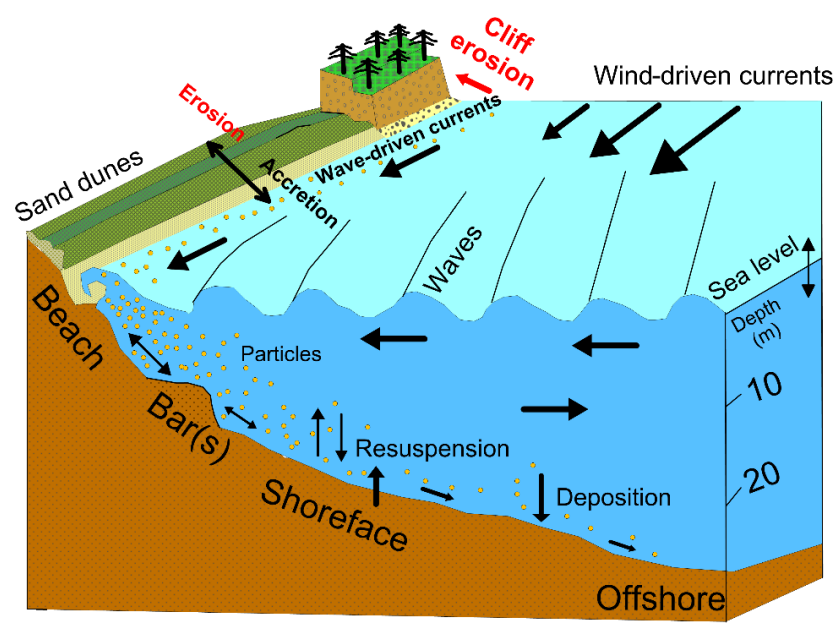

Figure 4. Main coastal topographic features and the erosion and accretion processes at the Baltic Sea shores (redrawn and modified from Harff et al., 2017).

proach the shore at high angles, and the effects of an individual storm on beach processes and sediment transport within a compartment can vary considerably depending on wind (and therefore wave) characteristics, overlying the effects of shortterm elevated water levels. Figure 4 provides a sketch of the main topographic coastal features and processes contributing to erosion and sedimentation at the Baltic Sea shores.

As part of the thematic Baltic Earth Assessment Reports, this study concentrates and reviews knowledge on sea level dynamics and coastal erosion in the Baltic Sea region. Section 2 provides an overview of the current state of knowledge for both mean and extreme sea levels as well as for 
coastal erosion and sedimentation. This includes brief recaps of sources of data and relevant processes along with descriptions of variability and past, ongoing, and potential future changes. Section 3 addresses several knowledge gaps that emerged from reviewing the available publications. Eventually, conclusions and key messages are presented in Sect. 4.

\section{Current state of knowledge}

\subsection{Mean sea level}

\subsubsection{Sources of data}

The primary sources for measuring mean sea level changes are tide gauges and radar altimetry from satellites. Both measure two different quantities, namely relative and absolute (geocentric) sea levels. Absolute sea level refers to the height of the sea surface relative to a geocentric reference, such as the reference ellipsoid, and is derived from satellite altimetry or GNSS-controlled tide gauges (where GNSS stands for global navigation satellite system; Schöne et al., 2009, 2011). Relative sea level refers to the height of the sea surface relative to the seafloor (or a local benchmark on land) and is derived from tide gauges or sea level reconstructions. Thus, contrary to the absolute sea level, the relative sea level is influenced both by variations in the height of the sea surface and by land uplift or subsidence.

The tide-gauge network of the Baltic Sea is one of the most densely spaced and longest-running networks in the world. Many stations have been in continuous operation since the early 19th century, and some stations have provided monthly averages for over 200 years (Ekman, 2009; Bogdanov et al., 2000; Kowalewska-Kalkowska and Marks, 2011). There are about 45 operational tide gauges with more than 60 years of data and with very good coverage of the western, southwestern, and northern Baltic Sea coasts (Hünicke et al., 2015). Eight additional gauges with data since 1961 in Latvian waters were recently added to this dataset (Männikus et al., 2019). Monthly averaged data are often provided to, and are open-access through, the Permanent Service for Mean Sea Level (PSMSL; e.g., Holgate et al., 2013). The Copernicus Marine Environment Monitoring Service collects data from a range of national stations at an hourly resolution with daily updates, although with varying quality control. The EMODnet Physics portal provides access to both data sources and, thus, combines a substantial number of longterm monthly and higher-frequency Baltic sea level measurements. The tide gauges measure relative to specific reference levels that differ between Baltic countries for historical reasons (Ekman, 2009). There are efforts to connect Baltic Sea gauges to a common datum, such as the Baltic Sea Chart Datum 2000 (BSCD2000; Schwabe et al., 2020). Additionally, uncertainties in local reference levels are introduced by factors including different measuring techniques and sampling frequencies (Ekman, 2009), changes in the reference points due to relocation of benchmarks, or anthropogenic changes in the tide-gauge surroundings, such as coastal or port development. Examples for the case of the Kronstadt gauge are described in Bogdanov et al. (2000). Phenomena occurring on timescales of years to decades such as subsidence (e.g., the sinking of piers due to unstable foundations or land sinking due to groundwater or gas extractions) can be other sources of uncertainties (Hünicke et al., 2015). Subsidence can further result from processes such as the compaction of unconsolidated alluvial soils, oxidation of organic materials, or increased surface load due to construction activities (e.g., Pelling and Blackburn, 2013).

Radar satellite altimetry from different satellite missions is available continuously from 1991 to the present (e.g., Schöne et al., 2010). Currently, the longest and most sound dataset is derived from a combination of the consecutive dual-frequency missions TOPEX/Poseidon, Jason-1, Jason2, and Jason-3 (Legeais et al., 2018). The orbit repeats itself every $10 \mathrm{~d}$, allowing for the construction of continuous time series since 1993. The missions form a pattern of ascending and descending orbits with an average cross-track distance of $100 \mathrm{~km}\left(\right.$ at $\left.60^{\circ} \mathrm{N}\right)$. Starting in 1991 with the European ERS-1 mission (followed by ERS-2, and the dual-frequency ENVISAT (European Space Agency - ESA) and AltiKa (In$\mathrm{dia} /$ France) mission), the Baltic Sea is also mapped every $35 \mathrm{~d}$ with an average cross-track distance of $55 \mathrm{~km}\left(\right.$ at $\left.60^{\circ} \mathrm{N}\right)$. With the launch of ESA's CryoSat-2 in 2010, a new altimetry concept was established using a synthetic aperture interferometric radar altimeter (SAR/SARin) to specifically map ice parameters but also sea surface heights closer to the coastlines. In 2016, the European Copernicus program launched a mission on Sentinel-3A (followed in 2018 by Sentinel3B) carrying forward the uninterrupted altimetry program with $27 \mathrm{~d}$ repeat periods. The recent launch of Sentinel-6A Michael Freilich in November 2020 will continue the important missions with unprecedented accuracy.

\subsubsection{Variability, change, and acceleration of Baltic Sea mean sea level}

Long-term changes in relative mean sea levels in the Baltic Sea are dominated by GIA, global sea level change, and other regional- to local-scale components and their interaction. This includes factors such as thermo- and halosteric contributions, or effects from long-term changes in wind and surface air pressure, currents in the North Atlantic that affect large-scale sea level, or variations in freshwater input in the Baltic Sea (Fig. 3).

Global mean sea level rise since the beginning of the last century was estimated from tide-gauge records with rates ranging between about 1 and $2 \mathrm{~mm} \mathrm{yr}^{-1}$ (e.g., Oppenheimer et al., 2019). For the era of continuously operated satellite radar altimeters beginning in 1991, higher estimates ranging between about 3 and $4 \mathrm{~mm} \mathrm{yr}^{-1}$ are reported (e.g., Nerem et al., 2018; Oppenheimer et al., 2019). These trends can- 

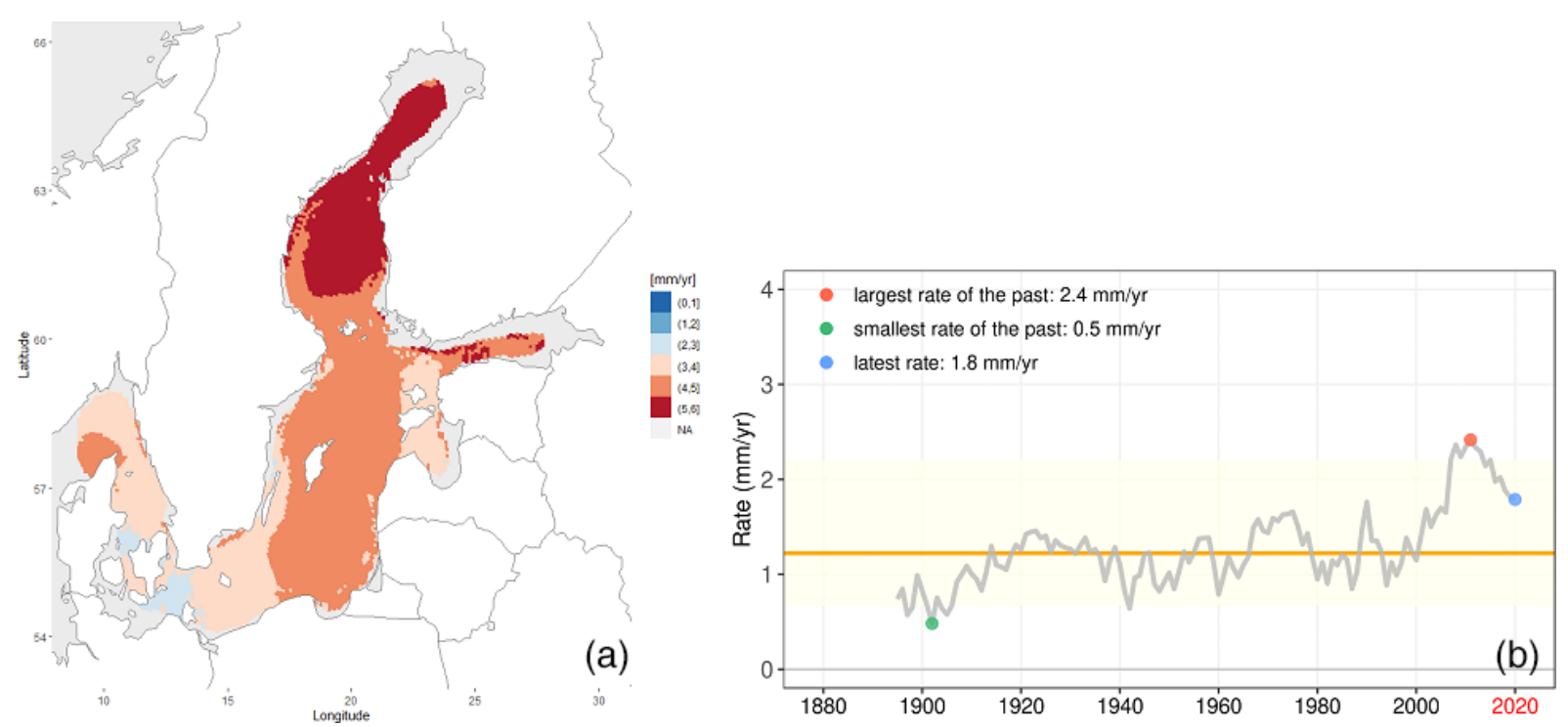

Figure 5. (a) Trends in annual absolute mean sea level from 1995 to 2019 derived from multi-mission satellite altimetry (redrawn and modified from Passaro et al., 2021.). Trends were provided by Baltic SEAL (https://balticseal.eu, last access: 13 August 2021). Data and methods are described in Passaro et al. (2021). (b) Time series of relative sea level trends in Warnemünde over successive 40-year periods (redrawn and modified from https://sealevel-monitor.eu/, last access: 13 August 2021): the trend in 2020 is representative of 1981-2020, the trend in 1980 is representative of 1941-1980, and so on. The orange line represents the median, and the yellow area is the 5\%-95\% range of all 40-year trends. Note that the vertical land movement at Warnemünde is close to zero $\left(0.55 \pm 0.59 \mathrm{~mm} \mathrm{yr}^{-1}\right.$; estimate provided by https://www.sonel.org, last access: 28 June 2021, for the last about 11 years).

not be directly compared because of the strong decadal variability inherent in the records (e.g., Fig. 5b; Albrecht et al., 2011) and their different spatial representativeness. As the majority of tide gauges is located at the coast, their data are more representative of coastal changes. Satellite data typically reflect open-ocean changes and variability. Also, inhomogeneous data, comprising a few tide-gauge records in the 19th and early 20th centuries and satellite data with nearly global coverage in the 21st century, hamper quantification and comparability of trends (Jevrejeva et al., 2008).

For the Baltic Sea, an increase in absolute mean sea level of about $3.3 \mathrm{~mm} \mathrm{yr}^{-1}$ was estimated based on available multi-mission 1992-2012 satellite altimetry data (Stramska and Chudziak, 2013). This figure is broadly consistent with the global average rate over that period. Current (1993-2015/2017) altimetry-derived Baltic Sea mean sea level trends are still comparable with the global average (Madsen et al., 2019a; Table 1). Across the Baltic Sea, the rates of absolute mean sea level rise vary between about 2 and $3 \mathrm{~mm} \mathrm{yr}^{-1}$ in the southwestern parts and about 5 and $6 \mathrm{~mm} \mathrm{yr}^{-1}$ in the northern parts for the period from 1995 to 2019 (Passaro et al., 2021; Fig. 5a).

Relative mean sea level changes and their secular trends are strongly affected by vertical land movements and vary considerably across the Baltic Sea. Geologically, the Baltic Sea region is divided into the uplifting Fennoscandian Shield in the north and the subsiding lowland parts in the south (Harff et al., 2007). Land uplift rates in the northern parts
Table 1. Rates of mean sea level rise for the Baltic Sea and estimated uncertainty ( 1 standard deviation range) based on Madsen et al. (2019a).

\begin{tabular}{lcc}
\hline & $\begin{array}{c}\text { Mean sea } \\
\text { level rise } \\
\left(\mathrm{mm} \mathrm{yr}^{-1}\right)\end{array}$ & $\begin{array}{c}\text { Uncertainty } \\
\left(\mathrm{mm} \mathrm{yr}^{-1}\right)\end{array}$ \\
\hline Statistical model, 1900-1999 & 1.3 & 0.3 \\
Statistical model, 1915-2014 & 1.6 & 0.3 \\
Statistical model, 1993-2014 & 3.4 & 0.7 \\
Satellite data (CCI*), 1993-2015 & 4.0 & 1.3 \\
\hline
\end{tabular}

* Here CCI refers to ESA Sea Level CCI ECV v2.0 (Quartly et al., 2017; Legeais et al., 2018).

are in the order of several millimeters per year and are comparable to the climatically induced rates of sea level rise in the 21st century. Relative mean sea level trends in the Baltic Sea show a corresponding north-south gradient, reflecting these crustal deformation rates due to GIA. In the northern parts, the relative mean sea level decreases with a maximum rate of about $8.2 \mathrm{~mm} \mathrm{yr}^{-1}$ in the Gulf of Bothnia (Hünicke et al., 2015). This corresponds to the area with maximum GIAinduced crustal uplift (Peltier, 2004; Lidberg et al., 2010). In the southern Baltic Sea, the relative mean sea level increases at a rate of about $1 \mathrm{~mm} \mathrm{yr}^{-1}$ with a gradient in a northeasterly direction (Richter et al., 2012; Groh et al., 2017). These findings are supported by numerous studies analyzing Baltic 
relative mean sea level trends on a national basis (Suursaar et al., 2006a; Dailidiené et al., 2012; Männikus et al., 2019). Different observation periods and analysis techniques hamper comparison to some extent. A more comprehensive figure on Baltic sea level trends and variability was provided by Madsen et al. (2019a), who used a statistical approach to combine data from century-long tide-gauge records with results from hydrodynamic modeling based on atmospheric reanalysis data and then compared the results with those from satellite altimetry records (Table 1). The analysis again emphasizes that the rate of sea level rise strongly depends on the period considered but that present-day rates are higher than those previously observed. This is also supported by an analysis of trends over successive 40-year periods at the Warnemünde tide gauge that shows pronounced variability in decadal sea level trends with present trends in the upper range of the observed values (Fig. 5b).

Atmospheric forcing in the form of wind and precipitation can affect the basin-average sea level (through changes in the total volume of water) as well as the internal distribution of water volume within the Baltic Sea basin. Winds, more particularly the strength of the westerly winds, modulate the exchange of water masses with the North Sea (Gräwe et al., 2019). During periods of weak or moderate wind conditions, a two-layer system of in- and outflow prevails in the Danish straits, whereas during periods of strong winds, in- or outflow occurs across the entire water column, the strength of which is controlled by the sea level gradient between the Kattegat and the western Baltic Sea (Sayin and Krauss, 1996; Stigebrandt, 1983; Mattsson, 1996). The alignment of the prevailing wind directions in this region with the geographical orientation of the connecting straits between the Baltic and the North seas favor conditions in which stronger than normal westerly winds push water masses into the Baltic Sea raising the overall sea level (with the inverse being true for weaker than normal westerly winds).

On average, there is a strong salinity increase from the northeast to the southwest of the Baltic Sea. This gradient results from the along-basin separation between the main saltwater (Danish straits) and freshwater (rivers discharging into the Gulf of Finland and the Bothnian Sea) sources. It leads, through density, to a corresponding sea level gradient which, in combination with the volume of the freshwater input and the effects of the prevailing westerly winds, gives rise to a corresponding sea level variation of about $35-50 \mathrm{~cm}$ across the Baltic Sea (Ekman and Mäkinen, 1996). Kniebusch et al. (2019) showed that there is pronounced decadal variability in the freshwater forcing, leading to a corresponding variability in the along-basin salinity gradient which, in turn, affects the sea level gradient. Over the period from 1900 to 2008, Kniebusch et al. (2019) also detected a trend in the salinity gradient but found the trend to be sensitive to the exact period chosen and small compared with the decadal variability. Likewise, precipitation anomalies affect the distribution of the Baltic mean sea level through corresponding changes in salinity and water density (Hünicke and Zorita, 2006). Currently, no robust long-term trends in the freshwater budget are observed (Johansson, 2016; Rutgersson et al., 2014) that would add to presently observed rates of Baltic sea level change.

The relation between Baltic sea level variability and the state of the large-scale atmospheric circulation has been the subject of numerous studies (Kahma, 1999; Johansson et al., 2001; Lehmann et al., 2002; Dailidienè et al., 2006; Hünicke and Zorita, 2006; Suursaar et al., 2006a; Johansson and Kahma, 2016; Chen and Omstedt, 2005; Omstedt et al., 2004). Mostly, these studies have focused on relations between the $\mathrm{NAO}^{1}$ and Baltic sea level. Generally, the positive phase of the NAO is associated with enhanced westerly winds over the Baltic Sea area, which causes the sea level to rise. Correlations strongly vary by region with higher values in the northern and the eastern parts and smaller values in the southern parts of the Baltic Sea. Moreover, the magnitude of the correlations is not constant and changed over the 20th century, including both periods with very high and very low values (Fig. 6). This suggests that the state of the NAO is a good but, for some periods, not the optimal indicator to describe Baltic sea level variability associated with the atmospheric circulation. Based on that finding, Karabil et al. (2018) suggested an alternative pattern based on the pressure differences between the Bay of Biscay and Troms $\emptyset$. Correlations between this new index (referred to by the authors as Baltic Sea and North Sea Oscillation or BANOS) and Baltic sea level variability were found to be more stable, suggesting that this index is better suited to describe the parts of Baltic sea level variability associated with the largescale atmospheric circulation (Fig. 6). Similar to the NAO, this new index exhibits pronounced interannual and decadal variability over approximately the past 120 years but does no show a significant long-term change (Karabil et al., 2018).

The contribution of the different mechanisms behind current sea level trends can be also estimated from the analysis of simulations with regional ocean models driven by observed atmospheric and global mean sea level forcing (Gräwe et al., 2019). This approach has the advantage that the effects of land movement on the Baltic sea level are explicitly neglected so that the contribution from other factors can be disentangled. In the simulation of Gräwe et al. (2019), the Baltic sea level rose at a rate of about $2 \mathrm{~mm} \mathrm{yr}^{-1}$ over the past 50 years, a rate that is slightly higher than the global average. Most of this sea level rise in the Baltic Sea was caused by a corresponding increase in the sea level in the North Atlantic Ocean. Model results along with data from Latvian waters (Männikus et al., 2020) further suggest a heterogeneous pat-

\footnotetext{
${ }^{1}$ The North Atlantic Oscillation (NAO) basically describes a meridional pattern in sea level pressure (SLP) with higher than normal SLP around the Azores and lower than normal SLP over Iceland and vice versa. Variability in this pattern is physically linked to the intensity of the westerlies in the European region.
} 

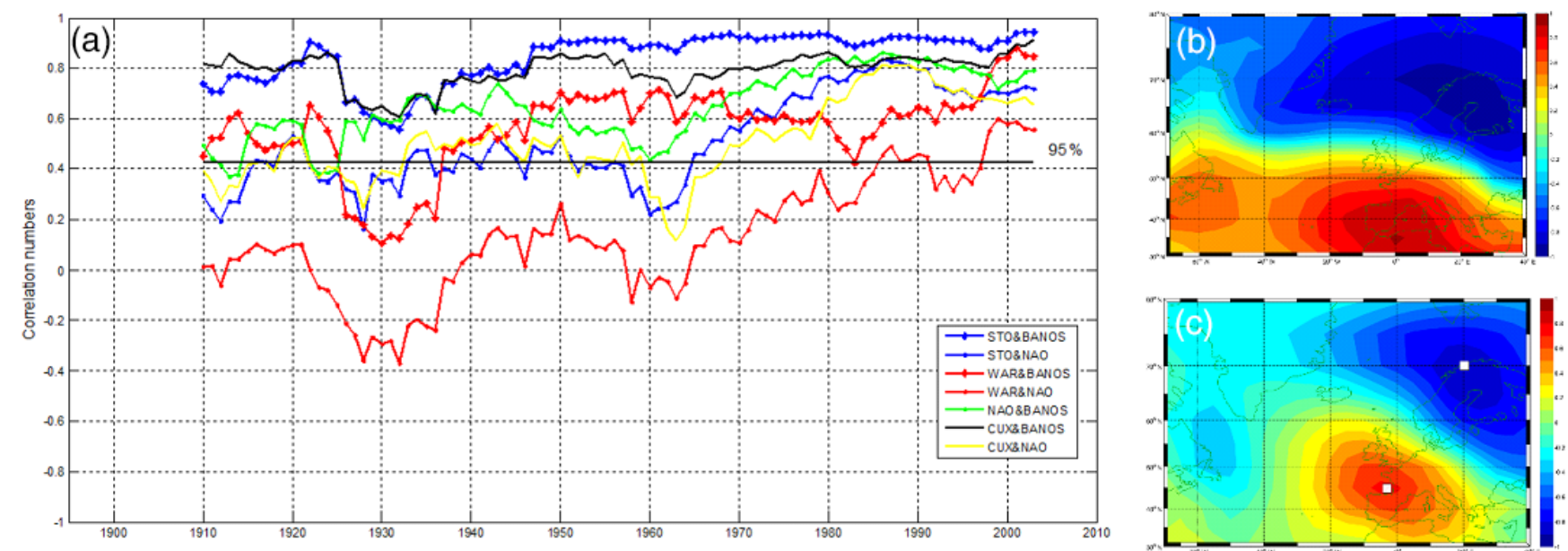

Figure 6. (a) Correlation between the NAO/the new index (BANOS) and winter mean sea level at Stockholm (STO), Warnemünde (WAR), and Cuxhaven (CUX) as well as the correlation between both indices. (b, c) Correlation maps for the periods when the correlation between the NAO and sea level variability were minimum (b) and maximum (c). The two white points in panel (c) were used to construct the new BANOS index. Reproduced from Karabil et al. (2018) and distributed under a CC-BY license.

tern of sea level rise, with larger rates in the northern Baltic Sea and smaller rates in the southeastern Baltic Sea, that appears to be the result of a poleward shift of atmospheric pressure systems (Gräwe et al., 2019).

For the future, global mean sea level rise is expected to have the largest impact on future Baltic sea level changes (Grinsted, 2015; Hieronymus and Kalén, 2020). It is anticipated that most of the future Baltic absolute sea level rise will be strongly linked with corresponding large-scale changes in the North Atlantic and the factors modulating these changes. These factors are mainly the thermal expansion of the water column, contributions from melting of the Antarctic ice sheet (Grinsted, 2015), and imprints from the variability and change in the Atlantic Meridional Overturning Circulation (Börgel et al., 2018).

For absolute sea level trends, the relative contribution from future melting of the Greenland and Antarctic ice sheets is the major source of spatial variation across the Baltic Sea. Melting of ice from the large ice sheets leads to changes in the Earth's gravitational field, rotation, and crustal deformation - the patterns of which are called sea level fingerprints (Plag and Jüttner, 2001). For any given place on Earth, these fingerprints are specific to the location of the ice melt. The Baltic sea level is substantially more sensitive to melting from Antarctica than from Greenland. For example, if an ice volume melts from Antarctica that is equivalent to an increase in the global mean sea level of $10 \mathrm{~cm}$, the increase in the absolute mean sea level in the Baltic Sea would be about $11 \mathrm{~cm}(+10 \%)$. If the same volume melts from the Greenland ice sheet, the response of the Baltic Sea level would be smaller and spatially more heterogeneous. Here, the values would vary around zero such that the southern Baltic Sea would experience an increase in absolute sea level of about $2 \mathrm{~cm}$ ( $20 \%$ of the globally averaged sea level rise from Greenland melting), while the northern Baltic Sea would expect a corresponding sea level fall (Hieronymus and Kalén, 2020).

For the Swedish coast, Hieronymus and Kalén (2020) provided sea level projections accounting for such variations. When compared to earlier estimates, this resulted in lower projections in 2100. However, as more recent estimates of potential future contributions from Antarctic melting increased (Oppenheimer et al., 2019), Hieronymus and Kalén (2020) still found their projections to be broadly consistent with earlier estimates, because their more careful treatment of spatial inhomogeneities was balanced by the larger estimates for Antarctic melting.

Stronger winds and increased runoff can further contribute to future Baltic sea level rise in the order of some centimeters (Meier, 2006; Hünicke, 2010; Johansson, 2014; Karabil, 2017; Pellikka et al., 2018). Future changes in the Baltic Sea freshwater budget may also affect the regional distribution of the Baltic mean sea level (Hünicke et al., 2017). If present links between atmospheric forcing and the Baltic mean sea level are extrapolated into the future, their contribution to the future Baltic mean sea level can be estimated from climate projections. Presently, such contributions are thought to be minor (Weisse and Hünicke, 2019). As GIA continues and will persist to dominate relative mean sea level changes in the northern parts of the Baltic Sea, these areas are expected to see a continued, although decelerated, decrease in relative mean sea level in the future, while the southern parts are expected to experience a relative mean sea level rise slightly exceeding the global average (Räisänen, 2017).

One of the expected implications of anthropogenic climate change would be an acceleration in sea level rise over 
time. So far, global mean sea level rise seems to have accelerated over the 20th century (Nerem et al., 2018; Oppenheimer et al., 2019; Dangendorf et al., 2019), although this is still a topic of ongoing debate (Kleinherenbrink et al., 2019; Veng and Andersen, 2020). Robust detection of acceleration is hampered to some extent by changes in the measurement system. While most of the data over much of the 20th century originate from coastal tide gauges mostly in the Northern Hemisphere, satellite altimetry has provided a nearly global figure mostly from the open ocean since 1991. Differences in estimates of satellite intra-mission biases also have substantial effects on estimated acceleration rates (Kleinherenbrink et al., 2019). As tide gauges in the Baltic Sea provide some of the longest, best quality controlled, and more homogeneous records, they may provide some support in assessing acceleration. From a statistical analysis of long Baltic sea level records, Hünicke and Zorita (2016) could indeed detect an acceleration in sea level rise. While the tests were not powerful enough to detect a significant acceleration in most of the records taken individually, results are robust for the set of gauges against different definitions of acceleration. The overall magnitude of the acceleration is small and, if continued unchanged over the whole 21 st century, would add just a few centimeters to the sea level rise. The latter is, however, unlikely, as an increase in the acceleration of sea level rise is expected for the future - in particular when the large ice sheets melt more rapidly.

Acceleration of Baltic sea level rise also displays a spatial pattern with accelerations in the northeastern parts 3 times as large as those in the southwest. The spatial structure is compatible with what would be expected from an expected deceleration of GIA. However, applying the theoretical deceleration calculated with models of the dynamics of the Earth's crust (Spada et al., 2014), the resulting order of magnitude is still too small to explain the apparent acceleration of relative coastal sea level. It has to be kept in mind that most tide gauges are affected by the rather strong noise of local vertical movements; thus, the detection of a second-order change, like acceleration, is challenging.

\subsection{Extreme sea levels and wind-generated waves}

\subsubsection{Sources of data}

Sea level extremes are measured using the same primary devices as for mean sea level: tide gauges and radar altimetry. For wind waves, data from visual observations, wave buoys, or radars mounted on platforms are also common. Spatial coverage of instrumental wave measurements in the Baltic Sea is scarce and limited to a few regions. So far, no longterm data exist from the central and eastern Baltic Proper and the Gulf of Riga (Suursaar et al., 2012). In the northern parts, measurements are often limited to ice-free periods, as buoys are usually removed during winter to prevent damage from ice. The homogeneity of data can be problematic due to ef- fects from the relocation of measurement sites or the replacement of instruments (Hünicke et al., 2015). Wave data from measurements are often used in combination with reconstructions from numerical wave hindcasts (Cieślikiewicz and Paplińska-Swerpel, 2008; Nikolkina et al., 2014; Björkqvist et al., 2018; Soomere et al., 2012), where they provide a reasonable characterization of open-sea wave fields.

\subsubsection{Variability and change in Baltic sea level extremes and wind-generated waves}

Baltic sea level extremes occur over a wide range of spatial and temporal scales. Contributions can arise from phenomena acting at small scales, such as wind-wave run-ups occurring at local scales with variations in the range of seconds, up to phenomena such as variations in the volume of the entire Baltic Sea characterized by formation timescales of up to a few weeks and even longer persistence (Soomere and Pindsoo, 2016). In between these ranges, other phenomena such as storm surges contribute to sea level extremes. All of these phenomena are generated mostly by meteorological and to some extent by astronomical factors (Weisse and Hünicke, 2019). From a climate perspective, this indicates that any relevant change in meteorological forcing may be associated with corresponding changes in Baltic sea level extremes.

The most prominent and most relevant phenomena contributing to sea level extremes in the Baltic Sea are storm surges, wind waves, and a preconditioning that leads to increased water volumes and, thus, sea levels in the entire Baltic Sea before the onset of a storm (Suursaar et al., 2006b; Madsen et al., 2015). Preconditioning is associated with periods of prevailing westerly winds that increase the sea level gradient across the Danish straits. In turn, the increased sea level gradient leads to higher inflow and higher Baltic Sea water volumes (Samuelsson and Stigebrandt, 1996). While the long-term average barotropic outflow from the Baltic Sea is about $7 \mathrm{~km}^{3} \mathrm{~d}^{-1}$ or $80000 \mathrm{~m}^{3} \mathrm{~s}^{-1}$ (Winsor et al., 2001), transports across the Danish straits can reach values of up to about $45 \mathrm{~km}^{3} \mathrm{~d}^{-1}$ in both directions, which corresponds to a sea level change of about $12 \mathrm{~cm} \mathrm{~d}^{-1}$ over the entire Baltic Sea (Mohrholz, 2018). Major inflow events are associated with typical volumes in the order of about $100 \mathrm{~km}^{3}$, corresponding to a Baltic sea level increase of about $24 \mathrm{~cm}$ (Matthäus and Franck, 1992). Typically, such variations have timescales of about $10 \mathrm{~d}$ or longer (Soomere and Pindsoo, 2016) while atmospheric variability on shorter timescales primarily leads to a redistribution of water masses within the Baltic Sea basin (Kulikov et al., 2015) or between the Baltic Proper and the Gulf of Riga (Männikus et al., 2019).

Storm surges refer to changes in the sea level in coastal waters that are primarily caused by the action of spatially varying atmospheric pressure on the sea surface (Pugh and Woodworth, 2014) and by wave setup in specific locations (Soomere et al., 2013). They represent a substantial threat 
to the low-lying coastal areas of the Baltic Sea, in particular in the southwestern regions (Wolski et al., 2014), the Gulf of Finland (Suursaar and Sooäär, 2016; Averkiev and Klevannyy, 2010), the Gulf of Riga (Suursaar and Sooäär, 2016; Männikus et al., 2019; Suursaar et al., 2006b), and the Gulf of Bothnia (Averkiev and Klevannyy, 2010). Comparing 50 years of hourly sea level data from gauges across the entire Baltic Sea, Wolski and Wiśniewski (2020) showed that Pärnu in the Gulf of Riga and Kemi in the Gulf of Bothnia are particularly prone to storm surges. In their analysis, these two gauges were characterized by both the highest average number of surges per year and the highest average number of hours per year with extreme sea levels. Regarding height, a surge in November 1824 in the Gulf of Finland was responsible for the highest recorded water level in the Baltic Sea (4.21 m above tide-gauge zero in St. Petersburg; Wolski and Wiśniewski, 2020). In the western Baltic Sea, a storm in November 1872 caused water levels to exceed $3 \mathrm{~m}$ at many gauges (Feuchter et al., 2013; Wolski and Wiśniewski, 2020). For the Gulf of Riga and the western Baltic Sea, respective storm surge heights of around $2 \mathrm{~m}$ and $1-1.5 \mathrm{~m}$ are typical (Wolski and Wiśniewski, 2020).

Storm surges in the Baltic Sea can last from several hours to almost a day (Wolski and Wiśniewski, 2020). Because of the seasonal cycle in wind speed, storm surges are highest and most frequent during fall and winter (Weidemann, 2014). The presence of sea ice may substantially reduce the effectiveness of wind in generating storm surges. In winter in the Gulf of Bothnia, the piling up of water is strongly suppressed by the existence of sea ice (Zhang and Leppäranta, 1995). When preconditioning exists - that is, high Baltic Sea water volumes - even moderate wind and wind surges may lead to coastal sea level extremes (e.g., Weisse and Weidemann, 2017).

Wind waves in the Baltic Sea show a pronounced seasonal cycle, with higher values in winter and lower values in summer. This behavior is associated with a corresponding seasonal cycle in wind speed (Björkqvist et al., 2018) and leads to extensive variations in the wave energy flux (Soomere and Eelsalu, 2014). Generally, waves are higher in open waters than in coastal waters. To date, the highest measured waves in the Baltic Sea have been reported from a wave buoy in the northern Baltic Proper. During a storm in December 2004, this buoy recorded a significant wave height of $8.2 \mathrm{~m}$ (Björkqvist et al., 2018; Tuomi et al., 2011). During windstorm Gudrun in 2005, measured significant wave heights reached $7.2 \mathrm{~m}$ in the Baltic Proper and $4.5 \mathrm{~m}$ in the Gulf of Finland. For this storm and away from sensors, model simulations suggested the existence of extreme significant wave heights of up to $9.5 \mathrm{~m}$ off the northwestern coast of Latvia (Soomere et al., 2008). More recently, very high waves with significant wave heights of up to $8.1 \mathrm{~m}$ have also been recorded in the Bothnian Sea (Björkqvist et al., 2020). However, in the Bothnian and the northern Baltic seas, the seasonal presence of sea ice typically modifies the wave climate and limits wave heights during the freezing season (Tuomi et al., 2011).

In the coastal zone, the height of the wave extremes is considerably smaller, but other wave-related processes such as wave setup or run-up (swash) can make substantial contributions to short-term sea level extremes. Wave setup refers to a wave-induced increase in the mean water level caused by the release of momentum from the dissipation of a long sequence of breaking waves, and swash is caused by the run-up of single waves on the beach (Melet et al., 2018). For example, for some coasts in the Gulf of Finland (Soomere et al., 2013, 2020) and along the shores of the West Estonian archipelago (Eelsalu et al., 2014), potential wave setup may reach values of up to 70-80 $\mathrm{cm}$. Moreover, the shape of the shoreline and irregular bottom topography can strongly modify local wave conditions (Tuomi et al., 2012, 2014), and wave setup and run-up may both have a strong influence on the level of flooding and erosion at the shore (Dean and Bender, 2006). Thus, coastal wave climate, its impacts, and its long-term changes strongly depend on location.

Changes in the Baltic Sea volume, storm surges, and extreme sea levels are tightly coupled. As increased volumes provide preconditioning for extremes in the entire sea (Pindsoo and Soomere, 2020), higher Baltic Sea volumes generally lead to higher extremes under otherwise similar storm conditions (Weisse and Weidemann, 2017). More specifically, westerly storms not only cause surges on the eastern Baltic Sea coast but also increase the volume of the sea. During subsequent storms, extreme sea levels are then higher than without preconditioning.

Two other noticeable effects may further contribute to Baltic sea level extremes: seiches and meteotsunamis. In the Baltic Sea, seiches with periods of up to tens of hours and $e$-folding times of up to $2 \mathrm{~d}$ may develop under certain atmospheric conditions (Leppäranta and Myrberg, 2009). Details of these oscillations are debated and are still not fully understood. From numerical studies, Wübber and Krauss (1979) proposed a series of basin-wide seiches with periods of up to $31 \mathrm{~h}$. Other authors have argued that the existence of such basin-wide oscillations is not entirely supported by data. Thus, they have suggested that such sea level oscillations in the Baltic Sea could alternatively be considered as an ensemble of weakly coupled local seiches with periods between 17 and $27 \mathrm{~h}$ in the Gulf of Riga, the Gulf of Finland, and the Belt Sea (Jönsson et al., 2008). Oscillations with similar periods also occur in the West Estonian archipelago (Otsmann et al., 2001). For the Gulf of Riga, Suursaar et al. (2002) also note the existence of a $5 \mathrm{~h}$ barotropic seiche. When favorably coupled with storm surges or in resonance with atmospheric forcing, such oscillations may contribute to very high sea level extremes at the coast (Suursaar et al., 2006a; Weisse and Weidemann, 2017; Wolski and Wiśniewski, 2020). Meteotsunamis are generated by moving atmospheric disturbances that trigger resonant sea level fluctuations. While not extremely frequent in the Baltic Sea, cases were described by 
Pellikka et al. $(2014,2020)$ for the Gulf of Finland or by Holfort et al. (2016) for the western Baltic Sea. Amplitudes may be in the order of $1 \mathrm{~m}$ (Pellikka et al., 2014, 2020).

The contribution from tides to the height of Baltic sea level extremes is mostly small, as the connection to the open ocean and, thus, co-oscillation is limited. Overall, tidal ranges are mostly between about 2 and $5 \mathrm{~cm}$ (Witting, 1911, as cited in Leppäranta and Myrberg, 2009). In the western sea areas, tidal ranges of up to 10-30 $\mathrm{cm}$ are observed (Defant, 1961, as cited in Leppäranta and Myrberg, 2009). Due to resonance, tidal ranges of up to $20 \mathrm{~cm}$ are also found near St. Petersburg at the end of the Gulf of Finland (Medvedev et al., 2013). While co-oscillation is limited, locally generated tides, albeit small, may also contribute in the same order of magnitude at some places (Schmager et al., 2008). In the western Baltic Sea, tidal conditions are predominantly semidiurnal, while in the Gulf of Finland and the Gulf of Riga, diurnal tides prevail (Medvedev et al., 2013; Schmager et al., 2008). While tidal ranges are generally small, they still have noticeable effects on the return periods of sea level extremes (Särkkä et al., 2017).

Variability and long-term changes in Baltic extreme sea levels can occur for various reasons but are primarily linked to changes in the relative mean sea level and atmospheric conditions. Relative mean sea level changes will modify the base upon which other atmospheric drivers of extremes will act, although the response is not necessarily linear (e.g., Arns et al., 2015). For example, for the same wind field, and hence surge levels, higher extremes are expected under higher relative mean sea levels. Also, changes in the driving atmospheric conditions will lead to changes in the statistics of waves, surges, and so on, which in turn will affect the sea level extremes. Moreover, nonlinear interaction between the contributions, potentially nonstationary behavior of the population of extremes (Kudryavtseva et al., 2018), and local effects such as from bathymetry or the shape of the coastline can make overall effects on sea level extremes highly nonadditive (e.g., Arns et al., 2015).

Based on tide-gauge data for different periods, several studies have revealed trends in Baltic sea level extremes. These trends were found to originate mainly from a corresponding change in mean sea level (Marcos and Woodworth, 2017; Ribeiro et al., 2014; Barbosa, 2008) or an increase in the magnitude of the preconditioning (Soomere and Pindsoo, 2016; Pindsoo and Soomere, 2020). For the periods from 1960 onwards, Marcos and Woodworth (2017) showed that the height and duration of sea level extremes increased or decreased at sites with a respective increasing or decreasing relative mean sea level and that these trends mostly disappear when the mean sea level signal is removed. Only for some of the eastern and northernmost stations do the trends indicate some contribution from corresponding changes in the large-scale atmospheric circulation and regional wind patterns (Barbosa, 2008; Ribeiro et al., 2014). Using data from a hindcast simulation ignoring GIA, Pindsoo

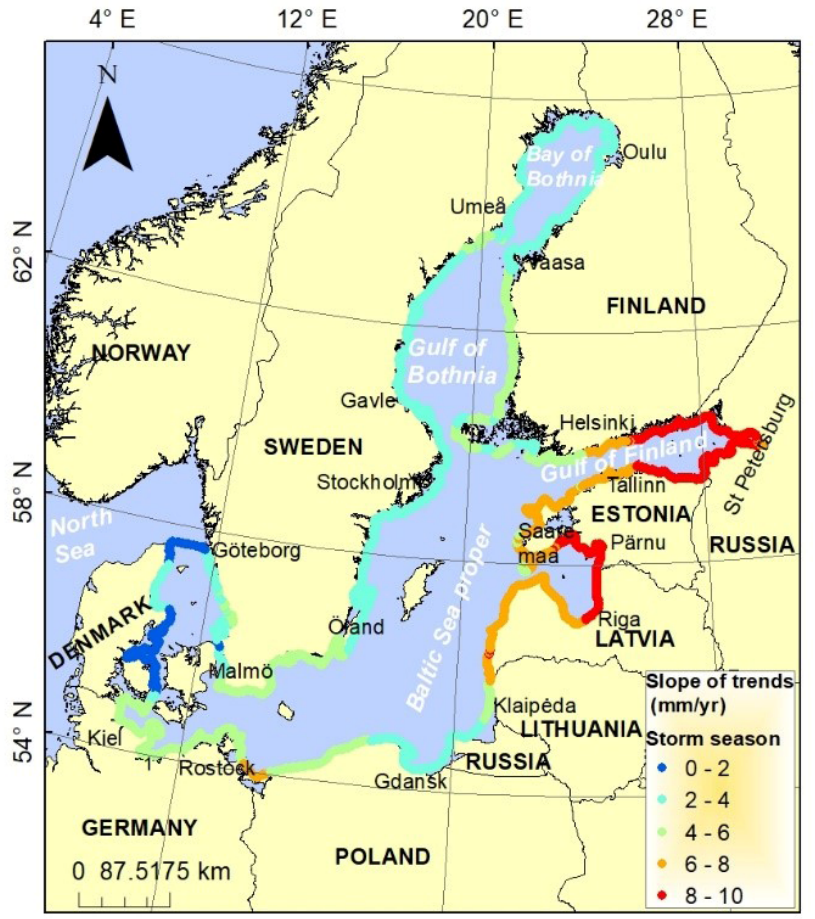

Figure 7. Trends of storm season (from July to June of the subsequent year) maximum water level derived from simulated total water level in 1961-2004/2005. Reproduced from Pindsoo and Soomere (2020) with permission from Elsevier and the authors.

and Soomere (2020) found increases in the height of Baltic sea level extremes for the period from 1961 to 2004/2005. These increases were strongest in the Gulf of Finland, the Gulf of Riga, and the eastern Baltic proper (Fig. 7). Pindsoo and Soomere (2020) concluded that the increases along the Swedish coast and the Gulf of Bothnia were almost entirely a result of global mean sea level rise and an increase in the maximum water volume of the entire sea. Conversely, they noted substantial contributions from stronger local storm surges to explain the higher values along the eastern shorelines.

Long-term changes in the wave climate may further contribute to changing extremes through corresponding adjustments of wave transformation in the surf zone (e.g., wave setup and swash). So far, there is no conclusive large-scale figure, and results vary strongly depending on the period and region. For the Arkona Basin, Soomere et al. (2012) analyzed wind-wave variability and trends based on 20 years of observation and a 45-year wave hindcast. They concluded that the wave height in this area exhibits no long-term trend but reveals modest inter-annual and substantial seasonal variations. For shorter periods (1993-2015), estimates from satellite altimetry data suggest a slight increase in annual mean significant wave height in the order of $10 \%$ (about $12 \mathrm{~cm}$ or $0.005 \mathrm{~m} \mathrm{yr}^{-1}$ ). Spatially, wave height increased in the central and western parts of the sea and decreased in the eastern parts 
(Kudryavtseva and Soomere, 2017). Nikolkina et al. (2014) analyzed a multi-ensemble wind-wave hindcast covering the entire Baltic Sea using different atmospheric forcing and periods (1970-2007 and 1957-2008). While these authors found the hindcasts consistently describing the known spatial patterns with relatively severe wave climate in the eastern parts of the Baltic proper and its subbasins, they could not infer consistent conclusions on long-term changes mainly due to differences in the atmospheric forcing used in the model simulations.

As for mean sea level, extreme sea levels are linked and correlated with the large-scale atmospheric circulation and its variability. The NAO is often used to characterize the state and the variability of the large-scale atmospheric circulation (Johansson, 2014; Marcos and Woodworth, 2018). There are several mechanisms that contribute to the link between Baltic sea level extremes and the NAO. The positive correlation between the phase of the NAO and mean sea level in the northwestern European shelf seas (Woolf et al., 2003) suggests that higher than normal mean sea levels occur during positive phases of the NAO. This would lead to an increase in the baseline sea level upon which wind- and pressure-induced extremes will act. In addition, there is also a positive relationship between the phase of the NAO and the frequency of westerly winds. Increased frequencies of westerly winds may lead to a higher than normal water volume in the Baltic Sea on average, which again would increase the baseline. Eventually, potential relationships between changes in the NAO and regional wind patterns would contribute to corresponding changes in wind surges and waves.

Using tide-gauge data, Johansson (2014) and Marcos and Woodworth (2018) showed that the positive correlation between the NAO and Baltic sea level extremes persisted even when long-term mean sea level changes were removed. This indicates that the NAO influences on Baltic sea level extremes are not only limited to the effects of changes in the mean but have contributions from NAO effects on Baltic Sea volume and/or locally generated wind surges and waves. This conclusion was further supported by a model study in which a coupled North and Baltic Sea model was forced solely by wind and sea level pressure from 1948 to 2011, thereby explicitly excluding effects from global mean sea level rise and rising temperatures (Weidemann, 2014). In this experiment, periods of high water volume in the Baltic Sea occurred more often during positive NAO phases and vice versa, and lower wind speeds were generally needed to sustain higher sea level extremes when the volume was above normal (Weisse and Weidemann, 2017).

Future changes in sea level extremes in the Baltic Sea crucially depend on two factors: future changes in relative mean sea level and future developments in large-scale atmospheric conditions associated with changing wind patterns. For some regions, changes in the frequency or thickness of sea ice may also have an impact. Relative sea level changes will strongly vary across the Baltic Sea because of the ex- isting spatial gradient in GIA and the spatial inhomogeneity associated with the uncertain relative contributions of melting from Antarctica and Greenland (see Sect. 2.1.2). For the Baltic Sea, changing mean sea levels are expected to have larger effects on future extremes than changing atmospheric circulation (Gräwe and Burchard, 2012). GIA is expected to continue at rates similar to those observed over the last century. Absolute mean sea levels are expected to rise in the entire Baltic Sea, but exact rates are uncertain and depend on the models, scenarios, and periods considered (see discussion in Sect. 2.1.2; Grinsted, 2015; Hieronymus and Kalén, 2020).

Potential future changes in long-term mean and extreme wind speeds are highly uncertain (Räisänen, 2017). In the Fifth Assessment Report of the Intergovernmental Panel on Climate Change (IPCC), a poleward shift of Northern Hemisphere midlatitude storm tracks and an ensemble average increase in the NAO index are reported as possible future developments (Kirtman et al., 2013). Because of the large internal variability and the large variability among models and scenarios, there was, however, only medium confidence in these projected changes (Kirtman et al., 2013). Recent studies indicate that the poleward shift of the westerlies is most pronounced in summer and less obvious in other seasons (Zappa and Shepherd, 2017). Because storm surges in the Baltic Sea are primarily a winter and fall phenomenon, this implies that contributions from changes in atmospheric circulation to future Baltic Sea storm surge climate remain uncertain. This is in agreement with climate model simulations investigated for the Second Assessment of Climate Change for the Baltic Sea Basin (BACC II Author Team, 2015) that were highly inconsistent for projected changes in wind speeds at the end of the 21 st century (Christensen et al., 2015; BACC II Author Team, 2015).

Despite these uncertainties, some storm surge and windwave projections seem to report relatively robust changes towards 2100. Using data from a multi-model ensemble, driven with atmospheric data from eight different climate models and the two Representative Concentration Pathway (RCP) emission scenarios RCP4.5 and RCP8.5, Vousdoukas et al. (2016) projected an increase in storm surge heights in the order of about $5 \%-10 \%$ across the entire Baltic Sea towards the end of the 21st century. For wind waves, Groll et al. (2017) reported an increase of about $5 \%-10 \%$ in mean and extreme wave heights using data from two realizations of two emission scenarios. In contrast, using a substantially larger ensemble consisting of data from six climate models and three emission scenarios, Dreier et al. (2021) found no consistent long-term changes in wave climate along the German Baltic Sea coast, and their projected changes in extreme wave height varied between about $-10 \%$ and $+6 \%$. This again suggests that projections of future wind waves and storm surges in the Baltic Sea are still highly dependent on the atmospheric scenario, the climate model, and the realization used for the projection. Nevertheless, because of the 
larger effect of changing mean sea levels on the extremes, regions with expected increases in relative mean sea level are still highly likely to experience an increase in sea level extremes.

\subsection{Coastal erosion and sedimentation}

\subsubsection{Sources of data}

Coastal erosion and sedimentation as well as longer-term shoreline changes tend to be researched at local, sediment compartment, or regional scales, where particular combinations of wind, wave, sediment characteristics and availability, and sea level variations and extremes at a range of scales can be considered. Generally, remote sensing data have been widely applied to investigate coastline change at various spatial and temporal scales. Different sources of remote sensing data include satellite images (e.g., Tiepold and Schuhmacher, 1999), aerial photographs (e.g., Furmanczyk et al., 2011; Dudzinska-Nowak, 2017), terrestrial (Eelsalu et al., 2015) and airborne laser scanning data (e.g., Hartleib and Bobertz, 2017), and orthophoto maps (e.g., Zhang et al., 2017; Dudzinska-Nowak, 2017). Such data were used, for example, to quantify the rates of coastline change over the past decades along the sandy southern Baltic Sea coast and more recently for the Russian waters (Ryabchuk et al., 2020). Also, historical maps with scales between $1: 250000$ and $1: 5000$ dating back to the 1820 s have provided useful information on the coastline change in the Baltic Sea at a longer timescale (Deng et al., 2017a; Hartleib and Bobertz, 2017). As tides are small in the Baltic Sea, the baseline of the seaward-most foredune or cliff, which represents the cumulative effect of deposition or erosion, has been used as an indicator to quantify coastline change (e.g., Dudzinska-Nowak, 2017; Zhang et al., 2015).

\subsubsection{Variability and change in erosion and sedimentation}

The Baltic Sea region can be geologically divided into the uplifting Fennoscandian Shield in the north and the subsiding lowlands in the south (for details, see Fig. 2.8 in Harff et al., 2007). Coastline change is characterized by a corresponding north-south gradient (Fig. 8) along which the main driving force gradually shifts from GIA to atmospheric and hydrodynamic forcing. Vertical land movement ranges from uplifts of up to almost $9 \mathrm{~mm} \mathrm{yr}^{-1}$ in the north to subsidence of up to $2 \mathrm{~mm} \mathrm{yr}^{-1}$ in the south. Since the onset of the Holocene, these vertical movements have caused a persistent marine regression at the northern coasts and a marine transgression along the southern coasts of the Baltic Sea (Harff et al., 2007, 2011). The transitional area between the northern uplift and the southern subsidence is located at the southern coast of the Gulf of Finland (Rosentau et al., 2017).

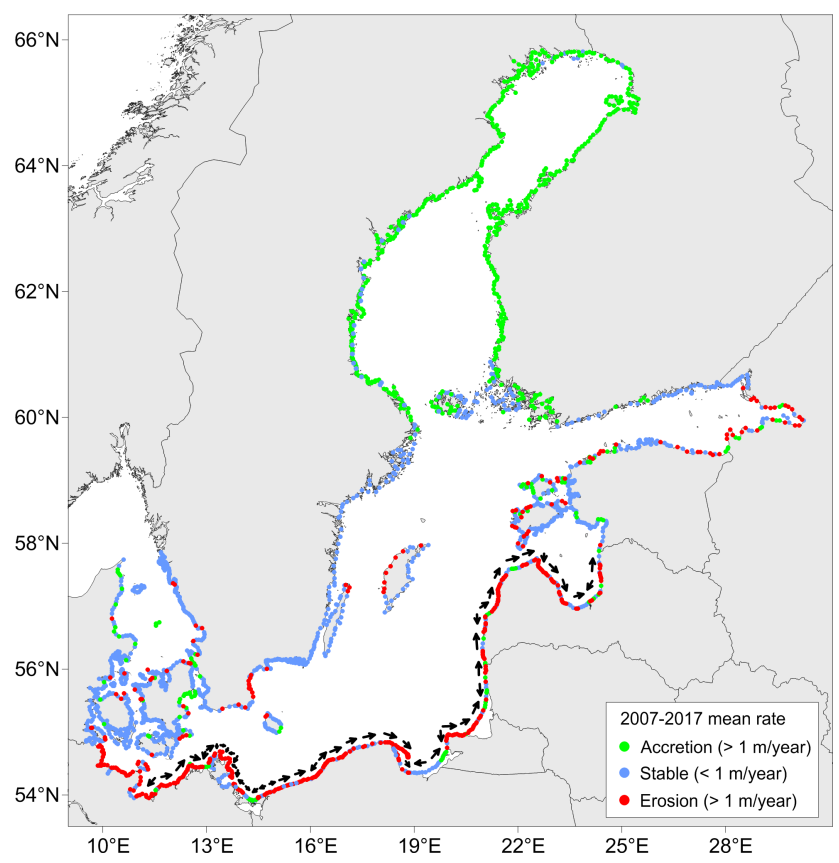

Figure 8. Rate of mean annual coastline change from 2007 to 2017 in the Baltic Sea based on a combination of satellite data for sandy beaches (Luijendijk et al., 2018) and field measurements for other coastline types (https://www.emodnet-geology.eu/, last access: 13 August 2021). Note that the accretion of the northern Baltic Sea coast is due to land uplift instead of sedimentation. The primary alongshore sediment transport direction along the sandy southern Baltic Sea coast is indicated by the arrows based on existing literature compiled by Harff et al. (2017).

About half of the shores of the Baltic Sea are comprised of either extremely resistant bedrock or relatively slowly changing cliffs of limestone or morainic materials. Due to this geology and the ongoing GIA, coastal erosion is not regarded as an issue of concern in Finland or for the majority of the Swedish coast (Pranzini and Williams, 2013). The other half of the Baltic Sea shores located primarily in the south and the east are sedimentary and are susceptible to coastline change due to erosion and accretion. This part of the coast is characterized by a series of barrier islands and sandy dunes connected with soft moraine cliffs. A typical crossshore dune profile at the southern Baltic coast features an established or a series of foredune ridges with typical heights between 3 and $12 \mathrm{~m}$ a.m.s.l. (meters above mean sea level) (Eabuz et al., 2018). At the backshore behind the established foredune ridges, drifting or stabilized dunes in transgressive forms are commonly developed. The source of sediment for dune development includes fluvioglacial sands from eroded cliffs, river-discharged sands, and older eroded dunes (Łabuz, 2015).

As with other (semi-)enclosed seas, dominant processes relevant for erosion and accretion on Baltic Sea shores differ from those described in the classic coastal process litera- 
ture. As on other shorelines, erosion is generally largest during storms when nearshore waves are longest, highest, and thus most energetic. Differences arise on Baltic Sea shorelines, however, from the lack of substantial tides, the lack of long wind-generated swell, the frequently occurring high angles of storm waves approaching the shore, and partially the presence of a seasonal ice cover. Wave energy and direction are the dominant drivers of sediment transport, erosion, and accretion in the Baltic Sea. Regional properties of the energy supply and the wave-driven transport are described in Soomere and Viška (2014), Kovaleva et al. (2017), or Björkqvist et al. (2018). A broader contextualization for the entire Baltic Sea can be found in Hünicke et al. (2015) and Harff et al. (2017).

On most shorelines, erosion is concentrated over relatively short periods around high tide, but as tides are very small in the Baltic Sea, elevated average water levels, which provide conditions conducive to erosion, can be maintained for extended periods (Johansson and Kahma, 2016; Soomere and Pindsoo, 2016). Therefore, Baltic Sea volume, storm surges, wave setup, the presence or absence of sea ice, and longperiod wave energy from infragravity or edge waves are the main factors influencing the duration and location on the beach profile where sediment can be mobilized and erosion may occur. Systematic synchronization of water level and wave intensity may considerably modify the width of the affected nearshore strip and the depth to which profile changes may occur (Soomere et al., 2017a).

The classic cut-and-fill concept of beach erosion and recovery (e.g., Brenninkmeyer, 1984) assumes that the most energetic steep waves induce beach erosion and mostly crossshore transport of sediment to the deeper part of the shore, while sandbar formation, transport of sediment onshore, and the accretion of the same beach appear during calmer wave conditions with less energy and longer wave periods (constructive swell). Thus, changes on the beach primarily follow the incident wave energy level (Masselink and Pattiaratchi, 2001). This cycle is less significant in the Baltic Sea where the wave regime is highly intermittent and contains very small proportions of low-intensity constructive long swell waves (Broman et al., 2006; Soomere et al., 2012). If waves approach the nearshore area at large angles with respect to shore-normal, the classic cut-and-fill cycle of beach change is modulated by a relatively intense alongshore movement of sediment when compared with open ocean shores with a similar wave intensity (Soomere and Viška, 2014).

While the strongest alongshore and cross-shore sediment transport in the nearshore area (surf and swash zones) usually takes place during extreme wave events, the most rapid shoreline changes (both erosion and accretion) occur when high waves attack the shore at relatively large angles (Ashton et al., 2001), in particular when the angle of wave approach is unusual for the specific location. The latter indicates that specific shore segments may be sensitive to erosion for a particular wave direction only. Several small pocket or headland- confined beaches with very small amounts of sand are in a fragile, yet almost equilibrium, state as they are geometrically protected against winds from many directions (Caliskan and Valle-Levinson, 2008).

Compared to average conditions in the world oceans, storm waves in the Baltic Sea often approach the shore at relatively large angles (Soomere and Viška, 2014; Pindsoo and Soomere, 2015). On open shores, such waves drive much more intense alongshore transport than waves of comparable height that approach the shore almost perpendicularly. When the approach angle exceeds a threshold of about $45^{\circ}$ (Ashton et al., 2001), the predominance of high-angle waves can lead to the explosive development of large spits and sand ridges. The growth of such structures has been observed in the eastern part of the Gulf of Finland (Ryabchuk et al., 2011b, 2020).

The presence of sea ice during a storm can modify this general pattern (Omstedt and Nyberg, 1991). The hydrodynamic forces are particularly effective in reshaping the shore when no sea ice is present and when the sediment is mobile (Orviku et al., 2003; Ryabchuk et al., 2011a). Storm surges are generally higher in the absence of sea ice (Omstedt and Nyberg, 1991). During extreme storm surges, strong waves may reach unprotected and unfrozen mobile sediment on higher sections of the shore that are out of reach for the waves during times with average water levels (Orviku et al., 2003). Land-ice interaction in the coastal zone is also crucial during ice winters. The principal erosion mechanisms are the wind-driven shore "ride-up" and pileup of ice and the ice growth down to the sea bottom with resulting transport of bottom sediment when the ice drifts out to sea (Girjatowicz, 2004; Leppäranta, 2013; Orviku et al., 2011). The former mechanism is also a risk to structures close to the shoreline.

Because of the dominant role of westerly winds that take up more than $60 \%$ of the year over the southern Baltic Sea (Zhang et al., 2011a) and the sheltering effect of the land in the west, wind waves are typically more developed in the eastern Baltic Sea than in the western part. As a result, sediment transport and dune development are generally more facilitated along the eastern and southeastern coast. For example, the coastal dunes with the largest size and height are developed along the Polish and the Lithuanian coast. Being open to large hydrodynamic loads over short periods, although with almost no low and long-period swell that is typically associated with beach accretion, Baltic Sea shorelines are conceptually vulnerable to erosion. Waves in the Baltic Sea are also relatively short, implying a narrow surf zone and less powerful wave run-up than on the open ocean shores.

The Baltic Sea wave climate is highly intermittent and anisotropic, following the intermittency and anisotropy of the wind climate; that is, there are only short periods and few directions from which the higher waves approach the shorelines. Only about $1 \%$ of the total onshore annual energy flux arrives within the calmest $170-200 \mathrm{~d}$, about $60 \%$ 

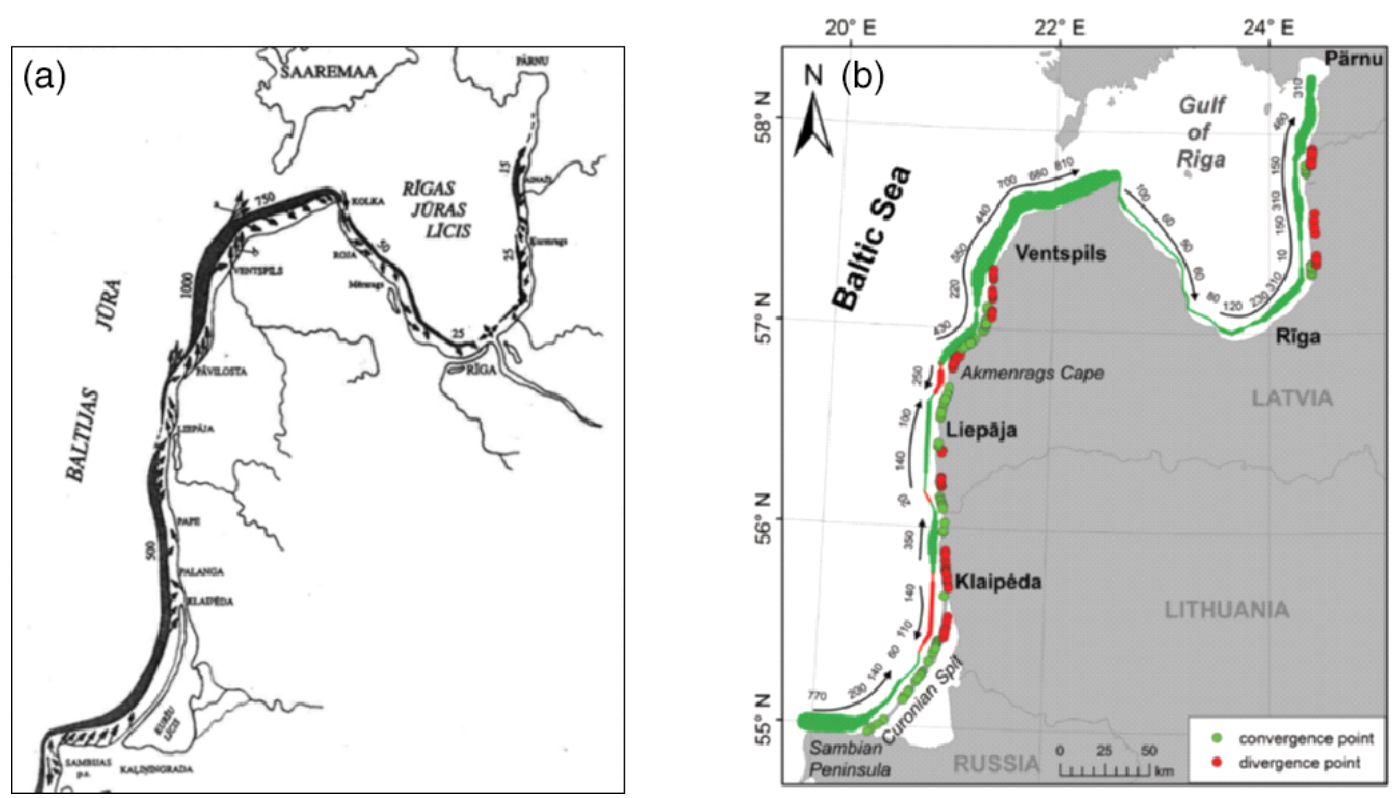

Figure 9. Direction (arrows) and magnitude (numbers at arrows, in $1000 \mathrm{~m}^{3}$ ) of net sediment transport: (a) original scheme by Rudolfs Knaps, amended by Ulsts (1998); (b) simulated potential net sediment transport (Viška and Soomere, 2013). Reproduced with permission from the authors and Baltica.

arrives within $20 \mathrm{~d}$, and as much as about $30 \%$ arrives during the stormiest 3-4 d (Soomere and Eelsalu, 2014). A simple consequence of the intermittency and anisotropy of wave fields and the complicated geometry of the coast is that the evolution of Baltic Sea shores is a steplike process (Soomere and Healy, 2011). They remain unchanged and seemingly stable for long periods until a storm from an unusual direction causes massive change. The most extreme erosion events will occur when such a combination comes along with high, normally storm-surge-related, water levels (Tõnisson et al., 2013b). However, most of the time, changes are very slow and require high-resolution measurements, such as laser scanning techniques (Eelsalu et al., 2015; Sergeev et al., 2018), to be detected. The anisotropy of the wave climate combined with the orientation of large sections of the shoreline leads to a large-scale asymmetry of the sediment flux (which is mostly counterclockwise on the shore of the Baltic Sea proper; Figs. 8, 9; Soomere and Viška, 2014). Owing principally to the overall sediment deficit on the Baltic Sea sedimentary shores (Pranzini and Williams, 2013), actual sediment transport is frequently limited by the availability of suitably sized sediment. Thus, the real sediment flux is only a few percent of the potential flux (Soomere and Viška, 2014). Consequently, there is only slow sediment accumulation in flux convergence areas (Fig. 9), and accumulation features may be destroyed easily as sediment transport during a single storm from an unusual direction may be substantially higher. This emphasizes the role of storms and storm waves in the Baltic Sea as substantial factors controlling sediment transport and coastal change.
Hydrodynamic conditions strongly affect coastal morphogenesis. Along the southern and eastern Baltic Sea coast, coastal morphogenesis has been extensively studied for more than a century (Keilhack, 1912; Kolp, 1978; Kliewe, 1995; Lampe et al., 2007; Zhang et al., 2010, 2014; Tõnisson et al., 2013a; Furmanczyk and Musielak, 2015; Harff et al., 2017; Deng et al., 2019). Barrier coasts are generally resilient to changing climate and can maintain their morphology provided that there is a neutral or positive sediment budget (Zhang et al., 2014) and beach migration is unimpeded (Cooper et al., 2020). The foredunes form a natural barrier for coastal protection along a major part of the southern Baltic coast. The part of the Baltic coastline that is protected by engineering structures or newly formed foredune ridges has been able to sustain its general shape and function (both ecological and economical) in the past decades, while most of the remaining parts, including the soft cliffs and old dune sections, have been subject to continuous and increased erosion (Łabuz, 2015). Most coastline erosion along the southern Baltic Sea is caused either by storms or by humaninduced depletion of sediment supply (e.g., as a side effect of engineering structures). Existing studies reveal a highly nonlinear relationship between storm intensity and the rate of coastline erosion along the southern Baltic Sea coast (Zhang et al., 2011b, 2015). Additionally, a strong relationship has been found between rates of coastline change and the relative level of human development. Even a local and modest level of development (e.g., beach nourishment and pier construction) was found to influence the long-term coastline change at larger spatial scales (up to $100 \mathrm{~km}$ ) (Deng et al., 2014; 
Dudzinska-Nowak, 2017). Because of this and the strong dependence on the angle at which the waves approach the shore, even smaller human interventions or a climate-related change in the predominant wind and wave directions in the Baltic Sea may substantially alter the structural patterns and pathways of wave-driven transport and functioning of large sections of the coastline (Viška and Soomere, 2012).

Human activities have become significant drivers of coastal change. With sediment transport being largely confined to shallow water, even smaller coastal construction works such as small boat harbors can significantly disrupt natural sediment transport pathways, leading to significant local (and frequently undesirable) coastal changes. Ship traffic, with the advent of strongly powered and fast large vessels, has become a significant driver of coastal processes and has caused erosion locally (Soomere et al., 2009). As is the case worldwide (UNEP, 2019), the demand for coastal sand for construction, industry, and beach nourishment will become increasingly significant for sediment supply.

\section{Knowledge gaps and further research challenges}

Baltic sea level dynamics and coastal erosion have been extensively studied for much longer than a century. Considerable progress has been made on both understanding details in the Baltic Sea and enhancing general knowledge. This has been possible due to the outstanding and long data records available in the Baltic Sea and the fact that processes relevant for understanding sea level dynamics and coastal erosion vary across short spatial distances and cover a broad range of timescales (Harff et al., 2017). Even so, when we compiled and reviewed the available publications and knowledge, we identified several gaps. We suggest that addressing these issues could substantially increase our knowledge of the Baltic and more generally contribute to an improved understanding of sea level dynamics, erosion, and coastline change. Without claiming completeness (and from our perspective), we provide a list of a few of the more relevant issues.

\subsection{Long-term changes}

A range for possible future Baltic relative mean sea level rise by the end of the 21st century assuming a scenario of strong greenhouse gas emissions (RCP8.5) was provided by Grinsted (2015). These estimates include contributions of the thermal expansion of the water volume in the North Atlantic, the transfer of water mass towards the coastal regions, the land movement caused by the GIA, and the contribution from melting of the Antarctic and Greenland ice sheets. In these estimates, the melting of the ice sheets represents the most uncertain factor. These processes are complex to simulate, as they include the dynamics of marine glaciers that are affected not only by the surface heat flux but also by ocean temperature variability and trends at very small spatial scales.
Thus, assessments of the contribution of such processes to sea level rise currently rely on estimates based on a mixture of model simulations that are difficult to validate as well as expert assessments (Bamber et al., 2019). For the Baltic sea level, the largest uncertainty arises from the melting of the Antarctic ice sheet. This is a consequence of contributions from self-gravitational effects, which, for the Baltic Sea, are much more strongly affected by the Antarctic than by Greenland melting (Mitrovica et al., 2001).

For the Baltic Sea coast, as for many coastal areas worldwide, there is a large variety of stakeholders with different levels of risk aversion, who need information on future sea level on different temporal and spatial scales (Madsen et al., 2019b; Gerkensmeier and Ratter, 2018; González-Riancho et al., 2017). For the Baltic Sea, the potential to provide such information has not yet been fully exploited. There are gaps in providing information that covers the whole range of available emission scenarios as well as in contextualizing such information. The latter includes the development of approaches on how evidence for high-end and plausible upper limits may be accounted for in reliable and acceptable ways (e.g., Thejll et al., 2020). This, in turn, calls for transdisciplinary approaches in which trust and co-creation of knowledge are fostered (Weisse et al., 2019; Schaper et al., 2019) and for the developments of frameworks (e.g., Stammer et al., 2019) accepted by both the scientific community and a wider range of stakeholders.

Coastal changes are strongly linked to changing extreme sea levels and strong wave conditions. Estimation and assessment of trends for extremes over centuries are still limited due to observational constraints and the rareness of extremes. Digitalization of the available historical data from analog archives or proxy analyses could improve the situation. Similarly, providing more comprehensive information on potential future developments comprising a larger range of available scenarios would be a step forward. In the view of on-going coastline change, approaches that account for the nonlinear interplay between mean and extreme sea level changes are required. This is especially needed, as the occurrence of extreme water levels in the Baltic Sea is not always well-described by classical statistical distributions (Johansson et al., 2001; Männikus et al., 2019). Furthermore, parameters of extreme value distributions vary in both space (Soomere et al., 2018) and time (Kudryavtseva et al., 2018).

There is an urgent need for improved modeling of extreme sea levels at finer spatial resolutions that are applicable to small coastal segments, which are sensitive to minor shifts in wind directions and intensities. This also applies to the modeling of wave properties, as the spatial resolutions of wave fields of about $500 \mathrm{~m}$ and even finer are necessary to adequately account for contributions of coastal processes such as wave setup on total nearshore water levels (Pindsoo and Soomere, 2015, 2020). Moreover, there are indications that the empirical distribution of setup heights in some coastal sections follows an inverse Gaussian distribution that sub- 
stantially complicates the construction of joint probability distributions of different components of extreme water levels (Soomere et al., 2020). There is also a need to better understanding the mechanisms and the long-term changes (mean, frequency, variability) of seiches and meteotsunamis.

Long-term changes in Baltic mean and extreme sea levels are strongly influenced by GIA. Thus, the quantification of land vertical velocities caused by GIA represents an important issue and source of uncertainty in determining longterm sea level changes. Generally, long-term GIA changes occur jointly with shorter-term land movements caused by factors such as construction works and gas and oil exploitation. Nowadays, land vertical velocities are measured relative to the geoid using the GNSS. However, such GNSS records are still short and show rather patchy patterns of land vertical velocities (Richter et al., 2012) in which the detection of GIA signals is hampered by short-term fluctuations. Moreover, trend differences over 2 decades of available data in vertical positions of GNSS antennae from stations separated by a few hundreds of kilometers may reach values of up to $2 \mathrm{~mm} \mathrm{yr}^{-1}$, which is comparable to the climate signal (Richter et al., 2012). Extrapolating these trends to the end of the 21st century yields relative sea level rise uncertainties in the order of $20 \mathrm{~cm}$, which can be substantial for some applications.

More recent publications have attempted to provide gridded estimates of GIA uplift based on a denser network of local observations (Vestøl et al., 2019). The uncertainty in these gridded datasets is in the order of $0.25 \mathrm{~mm} \mathrm{yr}^{-1}$ in areas close to the local station data but rapidly grows to values between about 1 and $3 \mathrm{~mm} \mathrm{yr}^{-1}$ in areas where nearby station data are unavailable. Along the Baltic Sea coast, the typical uncertainty is of the order of about $0.5 \mathrm{~mm} \mathrm{yr}^{-1}$, which is smaller than in previous estimates, but still substantial compared with the climate-related sea level rise. This calls for a more accurate estimation of the GIA and other contributions to vertical land movements (e.g., by combining observational data with the results of Earth's crust deformation models). A basin-wide database of historical tide-gauge data with a common reference would strongly support such efforts.

The GIA is a process of adjustment towards a new state of equilibrium in which the Earth's crust viscously adjusts to changes in ice load. While GIA is usually considered as constant for the timescales of contemporary sea level rise, GIA-related vertical velocities will become smaller over millennia and will become zero once the Earth's crust has completely adjusted. Even if such deceleration is small, the question remains as to whether it can be detected in sea level records, and if and how it can be separated from the possible climate-related sea level rise acceleration. Except for Spada et al. (2014), these questions are usually not addressed but may become more pressing in the future when the rates of sea level rise substantially increase relative to the present rates.

\subsection{Coastal satellite altimetry}

Sea level information derived from satellite data has become increasingly important over the past decades. The estimation of sea level trends and sea level variability from satellite altimetry requires several auxiliary data and environmental corrections to the radar measurements. Besides the internal measurement errors, these corrections account for most of the uncertainties in altimetry. While for most oceanographic applications the correction models are mature for the open ocean, these are still being researched near the coast and in enclosed or semi-enclosed seas. Concerning the Baltic Sea, the most important corrections to be discussed are the wet tropospheric attenuation correction, the ionospheric corrections, the barometric corrections, and, to a minor extent, ocean tides. The wet troposphere correction is estimated by employing radiometers carried on most modern satellites (except ERS-1 and ERS-2). This correction deteriorates near land, as the radiometer footprint is much larger than the altimeter footprint. As part of the ESA CCI (European Space Agency Climate Change Initiative), a new composite product was developed (GPD+; Fernandes et al., 2015) that combines different observations (e.g., radiometer, GNSS) in the vicinity of the satellite measurements. The estimation of ionospheric corrections is based on dualfrequency measurements of the altimeters. This correction also fails near the coast, and models, such as Global Ionospheric Maps (GIMs), are widely used to replace incorrect values near the coast, especially in areas with good GNSS coverage. The estimation of the mean sea level also often includes a correction of barotropic pressure change effects. A high-resolution barotropic model (Carrère and Lyard, 2003; Carrere et al., 2016) forced with pressure and wind fields from atmospheric analyses including inverse barometer corrections is often used. Although the model operates on finite element grids with improved resolution for the Baltic Sea, the available product is gridded on a $0.25^{\circ} \times 0.25^{\circ}$ grid only. Of minor importance, although especially important for variability studies, are ocean tides. Baltic Sea tides are small and often not well assessed in global tide models, which may increase the errors or introduce aliasing effects in variability studies. A recent study (Esselborn et al., 2018) aimed at the importance of the quality of satellite orbit solutions found surprisingly large annual error signals for the Baltic Sea when comparing orbit solutions provided by different originators.

Studies of coastal vulnerability, erosion, or the hazard potential along coastlines require sea level estimation as close as possible to the coastline. The conventional radar altimetry is available at a $1 \mathrm{~Hz}$ interval $(\sim 6.7 \mathrm{~km})$ along-track, and the illuminated footprint varies between 2 and $25 \mathrm{~km}$ diameter depending on the surface roughness. Several studies use high-rate data (10 to $40 \mathrm{~Hz}$ depending on the altimeter mission), often in combination with advanced signal processing technologies, such as the so-called "re-tracking" of in- 
dividual radar pulses, allowing the extraction of water levels closer to the shore. In recent years, SAR/SARin technology has been developed and employed in radar altimetry. The first altimeter with SAR/SARin capability was CryoSat2 (launch 2010), and it is now also used for Sentinel-3A and Sentinel-3B. A study by Dinardo et al. (2018) for the north and western Baltic Sea using CryoSat-2 data demonstrated the possibility of mapping the mean sea surface with reasonable quality to as close as $2 \mathrm{~km}$ to the coast. A similar study by Idžanović et al. (2018) for Norway also demonstrated the ability to map the sea surface close to the coast and under difficult topographic conditions (e.g., in fjords). Both studies also emphasized the importance of improved environmental corrections replacing standard products.

\subsection{Coastline changes and erosion}

A need for further high-resolution modeling of the basic process drivers of coastal change remains, particularly waves and the co-functioning of severe waves and high water levels. Wave models used for the Baltic Sea usually have spatial resolutions of about 2-3 nautical miles (see Björkqvist et al., 2018, for an overview). The most recent simulations of the entire Baltic Sea have resolutions of about 1 nautical mile (Björkqvist et al., 2018; Nilsson et al., 2019 ). For some confined areas such as Tallinn Bay (Soomere et al., 2007) or the sea area off Helsinki (Björkqvist et al., 2017), modeled datasets are available at higher resolution in the order of a few hundred meters. Given the complex shape of the sedimentary shoreline of the Baltic Sea, a resolution in the order of $500 \mathrm{~m}$ for relatively straight sections of the shoreline and up to 100-200 $\mathrm{m}$ for more complicated sections is highly desirable to resolve the existing pattern of sedimentary compartments and cells and to better understand the processes behind their development and stability.

One of the largest gaps is simply the scarcity of in situ data. Data on coastline changes are mainly collected by national agencies during geological and coastal surveys and are not systematically available (Madsen et al., 2018). Such data provide the backbone for the estimation of sediment fluxes, the identification of sediment compartments, or for filling gaps on shoreline relocation and for understanding and forecasting coastline changes. The development of a systematic database for the entire Baltic Sea would be a major step forward.

Despite intensive research (Pranzini and Williams, 2013), a comprehensive view of alongshore sediment transport and associated spatial and temporal variability along the subsiding southern Baltic Sea coast is still lacking (Harff et al., 2017). It is known that the major transport pathway is determined jointly by the angle of incidence of the prevailing waves and the alongshore currents. Due to the prevailing westerly winds, eastward (counterclockwise) transports dominate along major parts of the southern Baltic Sea coast. However, the intensity of secondary transport (usually rever- sals of the predominant transport pattern) induced by easterly and especially by northerly winds is less well understood. In particular along the southern coast, the sandy dunes and cliffs are exposed to the highest erosional impact when storm surges occur with northerly winds (Musielak et al., 2017). For some parts of the Baltic Sea coastline, alongshore transport is very sensitive to the angle of incidence of the waves due to the orientation of the coastline (Viška and Soomere, 2012), and several stretches have clockwise transport. For example, the incidence angle of westerly wind-waves at the western part of Wolin Island in Poland (Dudzinska-Nowak, 2017) and the coast of Lithuania and Latvia (Soomere et al., $2017 b$ ) is very small, and even small changes in wind direction (in the order of about $10^{\circ}$ ) could lead to a reverse of the alongshore transport direction. On these sections of the coast, coastline change is highly variable and extremely sensitive to future changes in wind-wave climate (Viška and Soomere, 2012). Approaches are needed for better quantification of changes and uncertainties, and frameworks are required to cope with uncertainties in coastal management.

There are major gaps in the understanding of the functioning of sedimentary compartments and cells and the wavedriven mobility of sediment between these cells in the eastern Baltic Sea (Soomere and Viška, 2014). Although many of the cells are quite large, many are also small (Soomere et al., 2007), requiring modeling and measurements at a much finer scale than is currently available. An approach to comprehensively quantify sediment budget regions with small-scale sedimentary compartments could be to combine (airborne and terrestrial) laser scanning measurements (Eelsalu et al., 2015) and detailed bathymetric data with high-resolution, possibly phase-resolving simulations of the nearshore wave climate. Underwater sediment transport and distribution changes could be roughly estimated from approximations such as the inverse Bruun rule (Eelsalu et al., 2015); however, more sophisticated techniques should be developed that systematically consider the alongshore transport.

There is currently no universally accepted model of coastal change under sea level rise (Le Cozannet et al., 2019). Indeed, even the assessment of the current state of the world's beaches is incomplete, including Europe and the Baltic Sea (Luijendijk et al., 2018). Simple approximations such as the Bruun rule are continuously applied (e.g., Vousdoukas et al., 2020) despite being widely criticized (Cooper and Pilkey, 2004; Le Cozannet et al., 2016; Cooper et al., 2020). For the Baltic Sea, existing efforts to model shoreline evolution have all focused on relatively short coastal sections (e.g., Zhang et al., 2015). Moreover, they have implicitly or explicitly assumed that the wind and wave climate was stationary over the modeled period (e.g., Deng et al., 2015). This assumption has been questioned implicitly by nonstationary modeling of water level extremes (Kudryavtseva et al., 2018, 2021). The extension of modeling capabilities to cover larger coastal segments and to include nonstationary wind and wave 
conditions is needed. While morphodynamic models are already capable of reproducing the main statistical properties of alongshore sediment transport, they are not yet suitable for capturing details of coastal evolution (Deng et al., 2017b). The latter would also include an improved understanding of the factors controlling the formation of the various types of coastal dunes and their interaction with adjoining morphological features such as cliffs, inlets, and engineering structures or the effect of structures and waterworks on coastline changes.

While there has been substantial progress in the development of coastal morphological models, a need remains for conceptual development (Hinkel et al., 2013; Vitousek et al., 2017) that takes the specifics of Baltic Sea conditions such as the modification of the classic cut-and-fill process or the high sensitivity to minor changes in the wind and wave climate (Viška and Soomere, 2012) into account. Major progress is expected from research that integrates modeling, measurement, and monitoring (Vitousek et al., 2017).

\subsection{Decadal predictability of mean and extreme sea levels}

Considerable efforts have been made to assess and understand past and possible future changes in mean and extreme sea levels. The assessment of future changes is mostly available for the end of the 21 st century or even longer time horizons. They are mostly available in the form of scenarios or projections - that is, in the form of conditional statements depending, for example, on future greenhouse gas emissions. However, there is a substantial societal need (e.g., Weisse et al., 2009, 2015) for improved information on the near-term regional climate that has stimulated considerable research in the field of decadal climate prediction (Meehl et al., 2009, 2014). Decadal predictions aim at filling the gap between short-term predictions and long-term projections typically aiming at the years around 2100. It is suggested that there is some skill required for such predictions, mainly for the following two reasons: first, the so-called climate change commitment arises because the warming of the ocean lags that of the land areas so that the atmosphere will continue to warm even if greenhouse gas emissions were stabilized today; second, the uncertainty from increased greenhouse gas forcing is much smaller for the near-future (Meehl et al., 2009).

The techniques required for such predictions have not been (and need to be) explored for Baltic mean and extreme sea levels. Both are strongly influenced by sea level in the North Atlantic and by the atmospheric and ocean circulation. The decadal predictability of Baltic sea levels is, therefore, linked to the predictability of the dynamical state of the North Atlantic ocean and the large-scale sea level pressure patterns. Decadal predictions are admittedly difficult and are still in the initial stage of development. However, decadal prediction schemes based on initialized simulations with Earth system models display moderate success in the prediction of sea surface temperatures in the North Atlantic Ocean, which is partly related to the temperature trend caused by climate change and to the genuine prediction of decadal fluctuations (Müller et al., 2014; Smith et al., 2019). Exploring decadal predictability of the Baltic sea level based on decadal predictions provided by Earth system models possibly downscaled with statistical methods or with regional models of the Baltic Sea would represent major progress and would provide useful information for both the scientific community and a large variety of diverse stakeholders.

\section{Conclusions and key messages}

Baltic sea level and coastline change have received considerable attention for centuries. As a consequence, the Baltic Sea tide-gauge network represents one of the most densely spaced networks comprising some of the longest available records worldwide. Many of the processes determining sea level dynamics and coastline change are relevant in the Baltic Sea where their relative contribution to the overall changes vary over short distances and across timescales. This has substantially contributed to the expansion of general concepts and of our present understanding of sea level and coastline change, and has similarly fostered a regional understanding of the implications of climate change in the Baltic Sea.

From a different (ecological) perspective, Reusch et al. (2018) concluded that "the Baltic Sea stands out in providing a strong scientific foundation and accessibility to longterm data series that provide a unique opportunity to assess the efficacy of management actions". We suggest that the same argument holds for sea level dynamics and coastal erosion and that global sea level research and research on coastline change could greatly benefit from research undertaken in the Baltic Sea. This is specifically due to the extremely large number of processes contributing to observed variability and change in the Baltic Sea. In combination with the outstanding data availability, they offer excellent research opportunities. Presently, the situation is different. Despite the dense observational network, the long records available, and the considerable progress made in the general understanding of global geophysical processes based on Baltic Sea data (Ekman, 2009; Omstedt, 2017), data from the Baltic Sea are often excluded in global sea level research (Jevrejeva et al., 2006). This is primarily because of the large number of processes contributing to Baltic Sea level variation and change, which makes interpretation difficult. We suggest that this represents opportunities rather than threats.

Data availability. No data sets were used in this article.

Author contributions. This paper is the product of a joint effort involving all co-authors. It represents the result of many fruitful discussions within the Baltic Earth community and a review of the 
existing literature. $\mathrm{AO}$ and RW drafted the introduction; $\mathrm{EZ}, \mathrm{BH}$, TiS, and RW were responsible for the sections on mean sea level; BH, EZ, KK, TiS, ID, KM, TaS, and RW contributed the sections on extreme sea level; and TaS, KP and WZ drafted the sections on coastal erosion and sedimentation. The sections on knowledge gaps, conclusions, and key messages are the result of a joint effort and discussions between all co-authors. All authors carefully read, commented on, and contributed to the paper. The final article was compiled by RW.

Competing interests. The authors declare that they have no conflict of interest.

Disclaimer. Publisher's note: Copernicus Publications remains neutral with regard to jurisdictional claims in published maps and institutional affiliations.

Special issue statement. This article is part of the special issue "The Baltic Earth Assessment Reports (BEAR)". It is not associated with a conference.

Acknowledgements. This work is a contribution to the Baltic Earth program (https://baltic.earth, last access: 13 August 2021) and is part of the Baltic Earth Assessment Reports.

Financial support. Tarmo Soomere acknowledges institutional support IUT33-3 from the Estonian Ministry of Education and Research via the Estonian Research Council and the European Economic Area (EEA) Financial Instrument 2014-2021 Baltic Research Programme project EMP480 "Solutions to current and future problems on natural and constructed shorelines, eastern Baltic Sea”. Kevin Parnell acknowledges the European Regional Development Fund program Mobilitas Pluss (reg. no. 20142020.4.01.16-0024) project MOBTT72. Kristine Madsen received funding from the Danish State through the Danish Climate Atlas.

The article processing charges for this open-access publication were covered by the Helmholtz-Zentrum Hereon.

Review statement. This paper was edited by Markus Meier and reviewed by two anonymous referees.

\section{References}

Albrecht, F., Wahl, T., Jensen, J., and Weisse, R.: Determining sea level change in the German Bight, Ocean Dynam., 61, 20372050, https://doi.org/10.1007/s10236-011-0462-z, 2011.

Arns, A., Wahl, T., Dangendorf, S., and Jensen, J.: The impact of sea level rise on storm surge water levels in the northern part of the German Bight, Coast. Eng., 96, 118-131, https://doi.org/10.1016/j.coastaleng.2014.12.002, 2015.
Ashton, A., Murray, A. B., and Arnault, O.: Formation of coastline features by large-scale instabilities induced by high-angle waves, Nature, 414, 296-300, https://doi.org/10.1038/35104541, 2001.

Averkiev, A. S. and Klevannyy, K. A.: A case study of the impact of cyclonic trajectories on sea-level extremes in the Gulf of Finland, Cont. Shelf Res., 30, 707-714, https://doi.org/10.1016/j.csr.2009.10.010, 2010.

BACC Author Team (Ed.): Assessment of Climate Change for the Baltic Sea Basin, Regional Climate Studies, Springer-Verlag, Berlin, Heidelberg, 2008.

BACC II Author Team (Ed.): Second Assessment of Climate Change for the Baltic Sea Basin, Regional Climate Studies, Springer International Publishing, Cham, 2015.

Bamber, J. L., Oppenheimer, M., Kopp, R. E., Aspinall, W. P., and Cooke, R. M.: Ice sheet contributions to future sea-level rise from structured expert judgment, P. Natl. Acad. Sci. USA, 116, 11195-11200, https://doi.org/10.1073/pnas.1817205116, 2019.

Barbosa, S. M.: Quantile trends in Baltic sea level, Geophys. Res. Lett., 35, L22704, https://doi.org/10.1029/2008GL035182, 2008.

BIFROST project members: GPS measurements to constrain geodynamic processes in Fennoscandia, Eos Trans. AGU, 77, 337341, https://doi.org/10.1029/96EO00233, 1996.

Björkqvist, J.-V., Tuomi, L., Fortelius, C., Pettersson, H., Tikka, K., and Kahma, K. K.: Improved estimates of nearshore wave conditions in the Gulf of Finland, J. Mar. Syst., 171, 43-53, https://doi.org/10.1016/j.jmarsys.2016.07.005, 2017.

Björkqvist, J.-V., Lukas, I., Alari, V., van Vledder, G. P., Hulst, S., Pettersson, H., Behrens, A., and Männik, A.: Comparing a 41-year model hindcast with decades of wave measurements from the Baltic Sea, Ocean Eng., 152, 57-71, https://doi.org/10.1016/j.oceaneng.2018.01.048, 2018.

Björkqvist, J.-V., Rikka, S., Alari, V., Männik, A., Tuomi, L., and Pettersson, H.: Wave height return periods from combined measurement-model data: A Baltic Sea case study, Nat. Hazards Earth Syst. Sci., 20, 3593-3609, https://doi.org/10.5194/nhess20-3593-2020, 2020.

Bogdanov, V. I., Medvedev, M. Y., Solodov, V. A., Trapeznikov, Y. A., Troshkov, G. A., and Trubitsina, A. A.: Mean monthly series of sea level observations (1777-1993) at the Kronstadt gauge, Reports of the Finnish Geodetic Institute, 2000, 1, Geodeettinen Laitos, Kirkkonummi, 34 pp., 2000.

Börgel, F., Frauen, C., Neumann, T., Schimanke, S., and Meier, H. E. M.: Impact of the Atlantic Multidecadal Oscillation on Baltic Sea Variability, Geophys. Res. Lett., 45, 9880-9888, https://doi.org/10.1029/2018GL078943, 2018.

Brenninkmeyer, B. M.: Cut and fill, in: Beaches and Coastal Geology, edited by: Schwartz, M., Springer US, New York, NY, 1984.

Broman, B., Hammarklint, T., Rannat, K., Soomere, T., and Valdmann, A.: Trends and extremes of wave fields in the northeastern part of the Baltic Proper, Oceanologia, 48, 165-184, 2006.

Caliskan, H. and Valle-Levinson, A.: Wind-wave transformations in an elongated bay, Cont. Shelf Res., 28, 1702-1710, https://doi.org/10.1016/j.csr.2008.03.009, 2008.

Carrère, L. and Lyard, F.: Modeling the barotropic response of the global ocean to atmospheric wind and pressure forcing comparisons with observations, Geophys. Res. Lett., 30, 1275, https://doi.org/10.1029/2002GL016473, 2003. 
Carrere, L., Faugère, Y., and Ablain, M.: Major improvement of altimetry sea level estimations using pressure-derived corrections based on ERA-Interim atmospheric reanalysis, Ocean Sci., 12, 825-842, https://doi.org/10.5194/os-12-825-2016, 2016.

Celsius, A.: Anmärkning om vattnets förminskande så I Östersiön som Vesterhafvet, Kongl. Swenska Wetenskaps Academiens, Handlingar, 33-50, 1743.

Chen, D. and Omstedt, A.: Climate-induced variability of sea level in Stockholm: Influence of air temperature and atmospheric circulation, Adv. Atmos. Sci., 22, 655-664, https://doi.org/10.1007/BF02918709, 2005.

Christensen, O. B., Kjellström, E., and Zorita, E.: Projected Change - Atmosphere, in: Second Assessment of Climate Change for the Baltic Sea Basin, Regional Climate Studies, edited by: The BACC II Author Team, Springer, Cham, https://doi.org/10.1007/978-3-319-16006-1_11, 2015.

Cieślikiewicz, W. and Paplińska-Swerpel, B.: A 44-year hindcast of wind wave fields over the Baltic Sea, Coast. Eng., 55, 894-905, https://doi.org/10.1016/j.coastaleng.2008.02.017, 2008.

Cooper, J. A. G. and Pilkey, O. H.: Sea-level rise and shoreline retreat: Time to abandon the Bruun Rule, Global Planet. Change, 43, 157-171, https://doi.org/10.1016/j.gloplacha.2004.07.001, 2004.

Cooper, J. A. G., Masselink, G., Coco, G., Short, A. D., Castelle, B., Rogers, K., Anthony, E., Green, A. N., Kelley, J. T., Pilkey, O. H., and Jackson, D. W. T.: Sandy beaches can survive sea-level rise, Nat. Clim. Change, 10, 993-995, https://doi.org/10.1038/s41558-020-00934-2, 2020.

Dailidiené, I., Davuliene, L., Tilickis, B., Stankevicius, A., and Myrberg, K.: Sea level variability at the Lithuanian coast of the Baltic Sea, Boreal Environ. Res., 11, 109-121, 2006.

Dailidienè, I., Davulienè, L., Kelpšaite, L., and Razinkovas, A.: Analysis of the Climate Change in Lithuanian Coastal Areas of the Baltic Sea, J. Coast. Res., 282, 557-569, https://doi.org/10.2112/JCOASTRES-D-10-00077.1, 2012.

Dangendorf, S., Hay, C., Calafat, F. M., Marcos, M., Piecuch, C. G., Berk, K., and Jensen, J.: Persistent acceleration in global sea-level rise since the 1960s, Nat. Clim. Change, 9, 705-710, https://doi.org/10.1038/s41558-019-0531-8, 2019.

Dean, R. G. and Bender, C. J.: Static wave setup with emphasis on damping effects by vegetation and bottom friction, Coast. Eng., 53, 149-156, https://doi.org/10.1016/j.coastaleng.2005.10.005, 2006.

Defant, A.: Physical Oceanography, Pergamon Press, New York, NY, 729 pp., 1961.

Deng, J., Zhang, W., Harff, J., Schneider, R., Dudzinska-Nowak, J., Terefenko, P., Giza, A., and Furmanczyk, K.: A numerical approach for approximating the historical morphology of wave-dominated coasts - A case study of the Pomeranian Bight, southern Baltic Sea, Geomorphology, 204, 425-443, https://doi.org/10.1016/j.geomorph.2013.08.023, 2014.

Deng, J., Harff, J., Schimanke, S., and Meier, H. E. M.: A method for assessing the coastline recession due to the sea level rise by assuming stationary wind-wave climate, Oceanol. Hydrobiol. Stud., 44, 362-380, https://doi.org/10.1515/ohs-2015-0035, 2015.

Deng, J., Harff, J., Giza, A., Hartleib, J., Dudzinska-Nowak, J., Bobertz, B., Furmanczyk, K., and Zölitz, R.: Reconstruction of coastline changes by the comparisons of historical maps at the
Pomeranian Bay, southern Baltic Sea, in: Coastline Changes of the Baltic Sea from South to East, 19, edited by: Harff, J., Furmańczyk, K. and von Storch, H., Springer International Publishing, Cham, 271-287, 2017a.

Deng, J., Woodroffe, C. D., Rogers, K., and Harff, J.: Morphogenetic modelling of coastal and estuarine evolution, Earth-Sci. Rev., 171, 254-271, https://doi.org/10.1016/j.earscirev.2017.05.011, $2017 \mathrm{~b}$.

Deng, J., Wu, J., Zhang, W., Dudzinska-Nowak, J., and Harff, J.: Characterising the relaxation distance of nearshore submarine morphology: A southern Baltic Sea case study, Geomorphology, 327, 365-376, https://doi.org/10.1016/j.geomorph.2018.11.018, 2019.

Dinardo, S., Fenoglio-Marc, L., Buchhaupt, C., Becker, M., Scharroo, R., Joana Fernandes, M., and Benveniste, J.: Coastal SAR and PLRM altimetry in German Bight and West Baltic Sea, Adv. Space Res., 62, 1371-1404, https://doi.org/10.1016/j.asr.2017.12.018, 2018.

Dreier, N., Nehlsen, E., Fröhle, P., Rechid, D., Bouwer, L., and Pfeifer, S.: Future Changes in Wave Conditions at the German Baltic Sea Coast Based on a Hybrid Approach Using an Ensemble of Regional Climate Change Projections, Water, 13, 167, https://doi.org/10.3390/w13020167, 2021.

Dudzinska-Nowak, P.: Morphodynamic processes of the Swina Gate coasta zone development (Southern Baltic Sea), in: Coastline Changes of the Baltic Sea from South to East, 19, edited by: Harff, J., Furmańczyk, K., and von Storch, H., Springer International Publishing, Cham, 219-255, 2017.

Eakins, B. W. and Sharman, G. F.: Volumes of the World's Oceans from ETOPO1, available at: https://www.ngdc.noaa.gov/mgg/ global/etopo1_ocean_volumes.html (last access: 18 April 2018), 2010.

Eelsalu, M., Soomere, T., Pindsoo, K., and Lagemaa, P.: Ensemble approach for projections of return periods of extreme water levels in Estonian waters, Cont. Shelf Res., 91, 201-210, https://doi.org/10.1016/j.csr.2014.09.012, 2014.

Eelsalu, M., Soomere, T., and Julge, K.: Quantification of changes in the beach volume by the application of an inverse of the Bruun Rule and laser scanning technology, Proc. Estonian Acad. Sci., 64, 240-248, https://doi.org/10.3176/proc.2015.3.06, 2015.

Ekman, M.: The world's longest sea level series and a winter oscillation index for Northern Europe, 1774-2000, Summer Institute for Historical Geophysics, Åland Islands, 31 pp., available at: https://www.historicalgeophysics.ax/sp/12.pdf (last access: 13 August 2021), 2003.

Ekman, M.: The changing level of the Baltic Sea during 300 years: A clue to understanding the earth, Summer Institute for Historical Geophysics, Godby, 155 pp., 2009.

Ekman, M.: The Man behind "Degrees Celsius": A Pioneer in Investigating the Earth and its Changes, Aland Islands, 159 pp., available at: https://www.historicalgeophysics.ax/books/ degrees_celsius.pdf (last access: 13 August 2021), 2016.

Ekman, M. and Mäkinen, J.: Mean sea surface topography in the Baltic Sea and its transition area to the North Sea: A geodetic solution and comparisons with oceanographic models, J. Geophys. Res., 101, 11993-11999, https://doi.org/10.1029/96JC00318, 1996.

Esselborn, S., Rudenko, S., and Schöne, T.: Orbit-related sea level errors for TOPEX altimetry at seasonal to decadal timescales, 
Ocean Sci., 14, 205-223, https://doi.org/10.5194/os-14-2052018, 2018.

Fernandes, M. J., Lázaro, C., Ablain, M., and Pires, N.: Improved wet path delays for all ESA and reference altimetric missions, Remote Sens. Environ., 169, 50-74, https://doi.org/10.1016/j.rse.2015.07.023, 2015.

Feuchter, D., Jörg, C., Rosenhagen, G., Auchmann, R., Martius, O., and Brönnimann, S.: The 1872 Baltic Sea storm surge, in: Weather extremes during the past 140 years, edited by: Brönnimann, S. and Martius, O., Geographica Bernensia, G89, 91-98, 2013.

Furmanczyk, K. and Musielak, S.: Polish spits and barriers, in: Sand and gravel spits, Coastal research library, 12, edited by: Randazzo, G., Jackson, D. W. T., and Cooper, J. A. G., Springer, Cham, 181-194, 2015.

Furmanczyk, K. K., Dudzinska-Nowak, J., Furmanczyk, K. A., Paplinska-Swerpel, B., and Brzezowska, N.: Dune erosion as a result of the significant storms at the western Polish coast (Dziwnow Spit example), J. Coast. Res., 64, 756-759, 2011.

Gerkensmeier, B. and Ratter, B. M. W.: Governing coastal risks as a social process - Facilitating integrative risk management by enhanced multi-stakeholder collaboration, Environ. Sci. Policy, 80, 144-151, https://doi.org/10.1016/j.envsci.2017.11.011, 2018.

Girjatowicz, J. P.: Ice thrusts and piles on the shores of the southern Baltic Sea coast (Poland) lagoons, Baltic Coast. Zone, 8, 5-22, 2004.

González-Riancho, P., Gerkensmeier, B., and Ratter, B. M. W.: Storm surge resilience and the Sendai Framework: Risk perception, intention to prepare and enhanced collaboration along the German North Sea coast, Ocean Coast. Manage., 141, 118-131, https://doi.org/10.1016/j.ocecoaman.2017.03.006, 2017.

Gräwe, U. and Burchard, H.: Storm surges in the Western Baltic Sea: The present and a possible future, Clim. Dynam., 39, 165183, https://doi.org/10.1007/s00382-011-1185-z, 2012.

Gräwe, U., Klingbeil, K., Kelln, J., and Dangendorf, S.: Decomposing Mean Sea Level Rise in a Semi-Enclosed Basin, the Baltic Sea, J. Climate, 32, 3089-3108, https://doi.org/10.1175/JCLI-D18-0174.1, 2019.

Grinsted, A.: Projected Change - Sea Level, in: Second Assessment of Climate Change for the Baltic Sea Basin, Regional Climate Studies, edited by: BACC II Author Team, Springer International Publishing, Cham, 253-263, 2015.

Groh, A., Richter, A., and Dietrich, R.: Recent Baltic Sea Level Changes Induced by Past and Present Ice Masses, in: Coastline Changes of the Baltic Sea from South to East, 19, edited by: Harff, J., Furmańczyk, K., and von Storch, H., Springer International Publishing, Cham, 55-68, 2017.

Groll, N., Grabemann, I., Hünicke, B., and Meese, M.: Baltic Sea wave conditions under climate change scenarios, Boreal Environ. Res., 22, 1-12, 2017.

Harff, J., Lemke, W., Lampe, R., Lüth, F., Lübke, H., Meyer, M., Tauber, F., and Schmölcke, U.: The Baltic Sea coast - A model of interrelations among geosphere, climate, and anthroposphere, in: Coastline Changes: Interrelation of Climate and Geological Processes, edited by: Harff, J., Hay, W. W., and Tetzlaff, D. M., Geological Society of America Special Paper 426, Geological Society of America, Penrose Place, USA, 133-142, 2007.
Harff, J., Meyer, M., Zhang, W., Barthel, A., and Naumann, M.: Holocene sediment dynamics at the southern Baltic Sea, Berichte der Römisch-Germanischen Kommission, 92, 41-76, 2011.

Harff, J., Deng, J., Dudzińska-Nowak, J., Fröhle, P., Groh, A., Hünicke, B., Soomere, T., and Zhang, W.: What Determines the Change of Coastlines in the Baltic Sea?, in: Coastline Changes of the Baltic Sea from South to East, 19, edited by: Harff, J., Furmańczyk, K., and von Storch, H., Springer International Publishing, Cham, 15-36, 2017.

Hartleib, J. and Bobertz, B.: New Demands on Old Maps - An Approach for Estimating Aspects of Accuracy of Old Maps as Basis for Landscape Development Research, in: Coastline Changes of the Baltic Sea from South to East, 19, edited by: Harff, J., Furmańczyk, K., and von Storch, H., Springer International Publishing, Cham, 257-270, 2017.

Hieronymus, M. and Kalén, O.: Sea-level rise projections for Sweden based on the new IPCC special report: The ocean and cryosphere in a changing climate, Ambio, 49, 1587-1600, https://doi.org/10.1007/s13280-019-01313-8, 2020.

Hinkel, J., Nicholls, R. J., Tol, R. S.J., Wang, Z. B., Hamilton, J. M., Boot, G., Vafeidis, A. T., McFadden, L., Ganopolski, A., and Klein, R. J. T.: A global analysis of erosion of sandy beaches and sea-level rise: An application of DIVA, Global Planet. Change, 111, 150-158, https://doi.org/10.1016/j.gloplacha.2013.09.002, 2013.

Holfort, J., Perlet, I., and Stanislawczyk, I.: Rapid changes in sea level, in: Multiple drivers for Earth system changes in the Baltic Sea region, International Baltic Earth Secretariat Publications 9, edited by: Reckermann, M. and Köppen, S., First Baltic Earth Conference, 13-17 June 2016, Nida, Curonian Spit, Lithuania, p. 119, avaliable at: https://www.baltic-earth.eu/imperia/md/assets/baltic_earth/ baltic_earth/baltic_earth/ibesp_no9_jun2016_nidaconf.pdf (last access: 13 August 2021), 2016.

Holgate, S. J., Matthews, A., Woodworth, P. L., Rickards, L. J., Tamisiea, M. E., Bradshaw, E., Foden, P. R., Gordon, K. M., Jevrejeva, S., and Pugh, J.: New Data Systems and Products at the Permanent Service for Mean Sea Level, J. Coast. Res., 29, 493504, https://doi.org/10.2112/JCOASTRES-D-12-00175.1, 2013.

Hünicke, B.: Contribution of regional climate drivers to future winter sea-level changes in the Baltic Sea estimated by statistical methods and simulations of climate models, Int. J. Earth Sci., 99, 1721-1730, https://doi.org/10.1007/s00531-009-0470-0, 2010.

Hünicke, B. and Zorita, E.: Influence of temperature and precipitation on decadal Baltic Sea level variations in the 20th century, Tellus A, 58, 141-153, https://doi.org/10.1111/j.16000870.2006.00157.x, 2006.

Hünicke, B. and Zorita, E.: Statistical Analysis of the Acceleration of Baltic Mean Sea-Level Rise, 1900-2012, Front. Mar. Sci., 3, 125, https://doi.org/10.3389/fmars.2016.00125, 2016.

Hünicke, B., Zorita, E., Soomere, T., Madsen, K. S., Johansson, M., and Suursaar, Ü.: Recent Change - Sea Level and Wind Waves, in: Second Assessment of Climate Change for the Baltic Sea Basin, Regional Climate Studies, edited by: BACC II Author Team, Springer International Publishing, Cham, 155-185, 2015.

Hünicke, B., Zorita, E., and von Storch, H.: The Challenge of Baltic Sea Level Change, in: Coastline Changes of the Baltic Sea from South to East, 19, edited by: Harff, J., Furmańczyk, K., and 
von Storch, H., Springer International Publishing, Cham, 37-54, 2017

Idžanović, M., Ophaug, V., and Andersen, O. B.: Coastal sea level from CryoSat-2 SARIn altimetry in Norway, Adv. Space Res., 62, 1344-1357, https://doi.org/10.1016/j.asr.2017.07.043, 2018.

Jakobsson, M., Stranne, C., O'Regan, M., Greenwood, S. L., Gustafsson, B., Humborg, C., and Weidner, E.: Bathymetric properties of the Baltic Sea, Ocean Sci., 15, 905-924, https://doi.org/10.5194/os-15-905-2019, 2019.

Jamieson, T. F.: On the History of the Last Geological Changes in Scotland, Quart. J. Geol. Soc., 21, 161-204, https://doi.org/10.1144/GSL.JGS.1865.021.01-02.24, 1865.

Jevrejeva, S., Grinsted, A., Moore, J. C., and Holgate, S.: Nonlinear trends and multiyear cycles in sea level records, J. Geophys. Res.-Oceans, 111, C09012, https://doi.org/10.1029/2005JC003229, 2006.

Jevrejeva, S., Moore, J. C., Grinsted, A., and Woodworth, P. L.: Recent global sea level acceleration started over 200 years ago?, Geophys. Res. Lett., 35, L08715, https://doi.org/10.1029/2008GL033611, 2008.

Johansson, J.: Total and Regional Runoff to the Baltic Sea, available at: https://helcom.fi/media/documents/BSEFS_ Total-and-regional-runoff-to-the-Baltic-Sea-in-2015.pdf (last access: 9 June 2021), 2016.

Johansson, M., Boman, H., Kahma, K. K., and Launiainen, J.: Trends in sea level variability in the Baltic Sea, Boreal Environ. Res., 6, 159-179, 2001.

Johansson, M. M.: Sea level changes on the finnish coast and their relationship to atmospheric factors, getr. Zählung, Contributions/Finnish Meteorological Institute, Finnish Meteorological Inst., Helsinki, 54 pp., 2014.

Johansson, M. M. and Kahma, K. K.: On the statistical relationship between the geostrophic wind and sea level variations in the Baltic Sea, Boreal Environ. Res., 21, 25-43, 2016.

Jönsson, B., Döös, K., Nycander, J., and Lundberg, P.: Standing waves in the Gulf of Finland and their relationship to the basin-wide Baltic seiches, J. Geophys. Res., 113, C03004,, https://doi.org/10.1029/2006JC003862, 2008.

Kahma, K.: Atlantin ilmanpaine vaikuttaa Itämereen [NAO is reflected in the Baltic sea level], Annual Report 1999, Finnish Institute of Marine Research, Helsinki, 1999.

Karabil, S.: Influence of Atmospheric Circulation on the Baltic Sea Level Rise under the RCP8.5 Scenario over the 21st Century, Climate, 5, 71, https://doi.org/10.3390/cli5030071, 2017.

Karabil, S., Zorita, E., and Hünicke, B.: Contribution of atmospheric circulation to recent off-shore sea-level variations in the Baltic Sea and the North Sea, Earth Syst. Dynam., 9, 69-90, https://doi.org/10.5194/esd-9-69-2018, 2018.

Keilhack, K.: Die Verlandung der Swinepforte, Jahrbuch der Königliche-Preussischen Geologischen Landesanstalt, XXXII, Königliche-Preussische Geologische Landesanstalt, Berlin, 209244, 1912

Kirtman, B., Power, S. B., Adedoyin, J. A., Boer, G. J., Bojariu, R., Camilloni,I., Doblas-Reyes, F. J., Fiore, A. M., Kimoto, M., Meehl, G. A., Prather, M., Sarr, A., Schär, C., Sutton, R., van Oldenborgh, G. J., Vecchi, G., and Wang, H. J.: Near-term Climate Change: Projections and Predictability, in: Climate Change 2013: The Physical Science Basis: Contribution of Working Group I to the Fifth Assessment Report of the Inter- governmental Panel on Climate Change, edited by: Stocker, T. F., Qin, D., Plattner, G.-K., Tignor, M., Allen, S. K., Boschung, J., Nauels, A., Xia, Y., Bex, V., and Midgley, P. M., Cambridge University Press, Cambridge, UK and New York, NY, USA, 2013.

Kleinherenbrink, M., Riva, R., and Scharroo, R.: A revised acceleration rate from the altimetry-derived global mean sea level record, Scient. Rep., 9, 10908, https://doi.org/10.1038/s41598019-47340-z, 2019.

Kliewe, H.: Zeit- und Klimamarken in Sedimenten der südlichen Ostsee und ihrer Vorpommerschen Boddenküste, J. Coast. Res., 17, 181-186, 1995.

Kniebusch, M., Meier, H. M., and Radtke, H.: Changing Salinity Gradients in the Baltic Sea As a Consequence of Altered Freshwater Budgets, Geophys. Res. Lett., 46, 9739-9747, https://doi.org/10.1029/2019GL083902, 2019.

Kolp, O.: Das Wachstum der Landspitze Darsser Ort, Petermanns Geogr. Mitt., 122, 3-111, 1978.

Kovaleva, O., Eelsalu, M., and Soomere, T.: Hot-spots of large wave energy resources in relatively sheltered sections of the Baltic Sea coast, Renew. Sustain. Energ. Rev., 74, 424-437, https://doi.org/10.1016/j.rser.2017.02.033, 2017.

Kowalewska-Kalkowska, H. and Marks, R.: 200 years of sea level measurements at the Swinoujscie tide gauge, in: Scientific symposium 200 years of oldest continuous record of tide-gauge in Swinoujscie, 18 November 2011, Swinoujscie, Poland, 2011.

Kudryavtseva, N. and Soomere, T.: Satellite altimetry reveals spatial patterns of variations in the Baltic Sea wave climate, Earth Syst. Dynam., 8, 697-706, https://doi.org/10.5194/esd-8-6972017, 2017.

Kudryavtseva, N., Pindsoo, K., and Soomere, T.: Non-stationary Modeling of Trends in Extreme Water Level Changes Along the Baltic Sea Coast, J. Coast. Res., 85, 586-590, https://doi.org/10.2112/SI85-118.1, 2018.

Kudryavtseva, N., Soomere, T., and Männikus, R.: Non-stationary analysis of water level extremes in Latvian waters, Baltic Sea, during 1961-2018, Nat. Hazards Earth Syst. Sci., 21, 1279 1296, https://doi.org/10.5194/nhess-21-1279-2021, 2021.

Kulikov, E. A., Medvedev, I. P., and Koltermann, K. P.: Baltic sea level low-frequency variability, Tellus A, 67, 25642, https://doi.org/10.3402/tellusa.v67.25642, 2015.

Łabuz, T.: Environmental Impacts - Coastal Erosion and Coastline Changes. in: Second Assessment of Climate Change for the Baltic Sea Basin, Regional Climate Studies, edited by: The BACC II Author Team, Springer, Cham, https://doi.org/10.1007/978-3-319-16006-1_20, 2015.

Łabuz, T. A., Grunewald, R., Bobykina, V., Chubarenko, B., Česnulevičius, A., Bautrènas, A., Morkūnaitè, R., and Tõnisson, H.: Coastal Dunes of the Baltic Sea Shores: A Review, Quaest. Geogr., 37, 47-71, https://doi.org/10.2478/quageo-2018-0005, 2018.

Lampe, R., Meyer, H., Ziekur, R., Janke, W., and Endtmann, E.: Holocene evolution of the irregularly sinking southern Baltic Sea coast and the interactions of sea-level rise, Berichte der RömischGermanischen Kommission, 88, 9-14, 2007.

Le Cozannet, G., Oliveros, C., Castelle, B., Garcin, M., Idier, D., Pedreros, R., and Rohmer, J.: Uncertainties in Sandy Shorelines Evolution under the Bruun Rule Assumption, Front. Mar. Sci., 3, 434, https://doi.org/10.3389/fmars.2016.00049, 2016. 
Le Cozannet, G., Bulteau, T., Castelle, B., Ranasinghe, R., Wöppelmann, G., Rohmer, J., Bernon, N., Idier, D., Louisor, J., and Salas-Y-Mélia, D.: Quantifying uncertainties of sandy shoreline change projections as sea level rises, Scient. Rep., 9, 42, https://doi.org/10.1038/s41598-018-37017-4, 2019.

Legeais, J.-F., Ablain, M., Zawadzki, L., Zuo, H., Johannessen, J. A., Scharffenberg, M. G., Fenoglio-Marc, L., Fernandes, M. J., Andersen, O. B., Rudenko, S., Cipollini, P., Quartly, G. D., Passaro, M., Cazenave, A., and Benveniste, J.: An improved and homogeneous altimeter sea level record from the ESA Climate Change Initiative, Earth Syst. Sci. Data, 10, 281-301, https://doi.org/10.5194/essd-10-281-2018, 2018.

Lehmann, A., Krauss, W., and Hinrichsen, H.-H.: Effects of remote and local atmospheric forcing on circulation and upwelling in the Baltic Sea, Tellus A, 54, 299-316, https://doi.org/10.1034/j.1600-0870.2002.00289.x, 2002.

Leppäranta, M.: Land-ice interaction in the Baltic Sea, Estonian J. Earth Sci., 62, 2-14, https://doi.org/10.3176/earth.2013.01, 2013.

Leppäranta, M. and Myrberg, K.: Physical oceanography of the Baltic Sea, Springer-Praxis books in geophysical sciences, Springer/Praxis Pub., Berlin, Chichester, UK, 2009.

Lidberg, M., Johansson, J. M., Scherneck, H.-G., and Milne, G. A.: Recent results based on continuous GPS observations of the GIA process in Fennoscandia from BIFROST, J. Geodynam., 50, 818, https://doi.org/10.1016/j.jog.2009.11.010, 2010.

Luijendijk, A., Hagenaars, G., Ranasinghe, R., Baart, F., Donchyts, G., and Aarninkhof, S.: The State of the World's Beaches, Scient. Rep., 8, 6641, https://doi.org/10.1038/s41598-018-24630-6, 2018.

Madsen, K. S., Høyer, J. L., Fu, W., and Donlon, C.: Blending of satellite and tide gauge sea level observations and its assimilation in a storm surge model of the North Sea and Baltic Sea, J. Geophys. Res.-Oceans, 120, 6405-6418, https://doi.org/10.1002/2015JC011070, 2015.

Madsen, K. S., She, J., Soomere, T., Pindsoo, K., Männikus, R., and Kudryavtseva, N.: Growth and innovation in ocean economy - gaps and priorities in Baltic Sea basin observation and data, EMODNET Baltic Sea Check Point for Challenge Area: Coastal Protection, available at: http://eurogoos.eu/download/project_deliverables/EMODnet2016-Baltic-Checkpoint-First-Data-Adequacy,-Report-2016.pdf (last access: 13 August 2021), 2018.

Madsen, K. S., Høyer, J. L., Suursaar, Ü., She, J., and Knudsen, P.: Sea Level Trends and Variability of the Baltic Sea From 2D Statistical Reconstruction and Altimetry, Front. Earth Sci., 7, 67, https://doi.org/10.3389/feart.2019.00243, 2019a.

Madsen, K. S., Murawski, J., Blokhina, M., and Su, J.: Sea Level Change: Mapping Danish Municipality Needs for Climate Information, Front. Earth Sci., 7, 113, https://doi.org/10.3389/feart.2019.00081, 2019b.

Männikus, R., Soomere, T., and Kudryavtseva, N.: Identification of mechanisms that drive water level extremes from in situ measurements in the Gulf of Riga during 1961-2017, Cont. Shelf Res., 182, 22-36, https://doi.org/10.1016/j.csr.2019.05.014, 2019.

Männikus, R., Soomere, T., and Viška, M.: Variations in the mean, seasonal and extreme water level on the Latvian coast, the eastern Baltic Sea, during 1961-2018, Estuar. Coast. Shelf Sci., 245, 106827, https://doi.org/10.1016/j.ecss.2020.106827, 2020.
Marcos, M. and Woodworth, P. L.: Spatiotemporal changes in extreme sea levels along the coasts of the North Atlantic and the Gulf of Mexico, J. Geophys. Res.-Oceans, 122, 7031-7048, https://doi.org/10.1002/2017JC013065, 2017.

Marcos, M. and Woodworth, P. L.: Changes in extreme sea levels, in: Sea level rise, edited by: Church, J., CLIVAR Exchanges, UCAR - University Corporation For Atmospheric Research, CLIVAR Exchanges, 74, 20-24, 2018.

Masselink, G. and Pattiaratchi, C. B.: Seasonal changes in beach morphology along the sheltered coastline of Perth, Western Australia, Mar. Geol., 172, 243-263, https://doi.org/10.1016/S00253227(00)00128-6, 2001.

Matthäus, W. and Franck, H.: Characteristics of major Baltic inflows - a statistical analysis, Cont. Shelf Res., 12, 1375-1400, https://doi.org/10.1016/0278-4343(92)90060-W, 1992.

Mattsson, J.: Some comments on the barotropic flow through the Danish Straits and the division of the flow between the Belt Sea and the Oresund, Tellus A, 48, 456-464, https://doi.org/10.1034/j.1600-0870.1996.t01-2-00007.x, 1996.

Medvedev, I. P., Rabinovich, A. B., and Kulikov, E. A.: Tidal oscillations in the Baltic Sea, Oceanology, 53, 526-538, https://doi.org/10.1134/S0001437013050123, 2013.

Meehl, G. A., Goddard, L., Murphy, J., Stouffer, R. J., Boer, G., Danabasoglu, G., Dixon, K., Giorgetta, M. A., Greene, A. M., Hawkins, E., Hegerl, G., Karoly, D., Keenlyside, N., Kimoto, M., Kirtman, B., Navarra, A., Pulwarty, R., Smith, D., Stammer, D., and Stockdale, T.: Decadal Prediction, B. Am. Meteorol. Soc., 90, 1467-1485, https://doi.org/10.1175/2009BAMS2778.1, 2009.

Meehl, G. A., Goddard, L., Boer, G., Burgman, R., Branstator, G., Cassou, C., Corti, S., Danabasoglu, G., Doblas-Reyes, F., Hawkins, E., Karspeck, A., Kimoto, M., Kumar, A., Matei, D., Mignot, J., Msadek, R., Navarra, A., Pohlmann, H., Rienecker, M., Rosati, T., Schneider, E., Smith, D., Sutton, R., Teng, H., van Oldenborgh, G. J., Vecchi, G., and Yeager, S.: Decadal Climate Prediction: An Update from the Trenches, B. Am. Meteorol. Soc., 95, 243-267, https://doi.org/10.1175/BAMS-D-12$00241.1,2014$.

Meier, H. E. M.: Baltic Sea climate in the late twenty-first century: A dynamical downscaling approach using two global models and two emission scenarios, Clim. Dynam., 27, 39-68, https://doi.org/10.1007/s00382-006-0124-x, 2006.

Melet, A., Meyssignac, B., Almar, R., and Le Cozannet, G.: Underestimated wave contribution to coastal sea-level rise, Nat. Clim. Change, 8, 234-239, https://doi.org/10.1038/s41558-018-0088y, 2018.

Milanković, M.: Théorie mathématique des phénomènes thermiques produits par la radiation solaire, Académie Yougoslave des Sciences et des Arts de Zagreb/Gauthier-Villars et Cie, Paris, 338 pp., 1920.

Mitrovica, J. X., Tamisiea, M. E., Davis, J. L., and Milne, G. A.: Recent mass balance of polar ice sheets inferred from patterns of global sea-level change, Nature, 409, 1026-1029, https://doi.org/10.1038/35059054, 2001.

Mohrholz, V.: Major Baltic Inflow Statistics - Revised, Front. Mar. Sci., 5, 280, https://doi.org/10.3389/fmars.2018.00384, 2018.

Müller, W. A., Pohlmann, H., Sienz, F., and Smith, D.: Decadal climate predictions for the period 1901-2010 with a cou- 
pled climate model, Geophys. Res. Lett., 41, 2100-2107, https://doi.org/10.1002/2014GL059259, 2014.

Musielak, S., Furmanczyk, K., and Bugajny, N.: Factors and processes forming the Polish southern Baltic Sea coast on various temporal and spatial scales, in: Coastline Changes of the Baltic Sea from South to East, 19, edited by: Harff, J., Furmańczyk, K., and von Storch, H., Springer International Publishing, Cham, 69-86, 2017.

Nerem, R. S., Beckley, B. D., Fasullo, J. T., Hamlington, B. D., Masters, D., and Mitchum, G. T.: Climatechange-driven accelerated sea-level rise detected in the altimeter era, P. Natl. Acad. Sci. USA, 115, 2022-2025, https://doi.org/10.1073/pnas.1717312115, 2018.

Nikolkina, I., Soomere, T., and Raamet, A.: Multidecadal ensemble hindcast of wave fields in the Baltic Sea, in: 2014 IEEE/OES Baltic International Symposium (BALTIC), Tallinn, Estonia, 19, 2014.

Nilsson, E., Rutgersson, A., Dingwell, A., Björkqvist, J.-V., Pettersson, H., Axell, L., Nyberg, J., and Strömstedt, E.: Characterization of Wave Energy Potential for the Baltic Sea with Focus on the Swedish Exclusive Economic Zone, Energies, 12, 793, https://doi.org/10.3390/en12050793, 2019.

Omstedt, A.: Guide to Process Based Modeling of Lakes and Coastal Seas, Springer International Publishing, Cham, 2015.

Omstedt, A.: The Development of Climate Science of the Baltic Sea Region, in: Oxford Research Encycolpedia, Climate Science, 1, Oxford University Press, Oxford, 2017.

Omstedt, A. and Nyberg, L.: Sea level variations during ice-covered periods in the Baltic Sea, Geophysica, 27, 41-61, 1991.

Omstedt, A., Pettersen, C., Rodhe, J., and Winsor, P.: Baltic Sea climate: $200 \mathrm{yr}$ of data on air temperature, sea level variation, ice cover, and atmospheric circulation, Clim. Res., 25, 205-216, https://doi.org/10.3354/cr025205, 2004.

Oppenheimer, M., Glavovic, B. C., Hinkel, J., van de Wal, R., Magnan, A. K., Abd-Elgawad, A., Cai, R., Cifuentes-Jara, M., DeConto, R. M., Ghosh, T., Hay, J., Isla, F., Marzeion, B., Meyssignac, B., and Sebesvari, Z.: Sea Level Rise and Implications for Low-Lying Islands, Coasts and Communities, in: IPCC Special Report on the Ocean and Cryosphere in a Changing Climate, edited by: Pörtner, H.-O., Roberts, D. C., MassonDelmotte, V., Zhai, P., Tignor, M., Poloczanska, E., Mintenbeck, K., Alegría, A., Nicolai, M., Okem, A., Petzold, J., Rama, B., and Weyer, N. M., IPCC, 2019.

Orviku, K., Jaagus, J., Kont, A., Ratas, U., and Rivis, R.: Increasing Activity of Coastal Processes Associated with Climate Change in Estonia, J. Coast. Res., 19, 364-375, 2003.

Orviku, K., Jaagus, J., and Tõnisson, H.: Sea ice shaping the shores, J. Coast. Res., SI64, 681-685, 2011.

Otsmann, M., Suursaar, Ü., and Kullas, T.: The oscillatory nature of the flows in the system of straits and small semienclosed basins of the Baltic Sea, Cont. Shelf Res., 21, 1577-1603, https://doi.org/10.1016/S0278-4343(01)00002-4, 2001.

Passaro, M., Müller, F. L., Oelsmann, J., Rautiainen, L., Dettmering, D., Hart-Davis, M. G., Abulaitijiang, A., Andersen, O. B., Høyer, J. L., Madsen, K. S., Ringgaard, I. M., Särkkä, J., Scarrott, R., Schwatke, C., Seitz, F., Tuomi, L., Restano, M., and Benveniste, J.: Absolute Baltic Sea Level Trends in the Satellite Altimetry Era: A Revisit, Front. Mar. Sci., 8, 7, https://doi.org/10.3389/fmars.2021.647607, 2021.
Pellikka, H., Rauhala, J., Kahma, K. K., Stipa, T., Boman, H., and Kangas, A.: Recent observations of meteotsunamis on the Finnish coast, Nat. Hazards, 74, 197-215, https://doi.org/10.1007/s11069-014-1150-3, 2014.

Pellikka, H., Leijala, U., Johansson, M. M., Leinonen, K., and Kahma, K. K.: Future probabilities of coastal floods in Finland, Cont. Shelf Res., 157, 32-42, https://doi.org/10.1016/j.csr.2018.02.006, 2018.

Pellikka, H., Laurila, T. K., Boman, H., Karjalainen, A., Björkqvist, J.-V., and Kahma, K. K.: Meteotsunami occurrence in the Gulf of Finland over the past century, Nat. Hazards Earth Syst. Sci., 20, 2535-2546, https://doi.org/10.5194/nhess-20-2535-2020, 2020.

Pelling, M. and Blackburn, S. (Eds.): Megacities and the coast: Risk, resilience and transformation, Routledge, London, 245 pp., 2013.

Peltier, W. R.: Global Glacial Isostasy And The Surface Of The Ice-Age Earth: The ICE-5G (VM2) Model and GRACE, Annu. Rev. Earth Planet. Sci., 32, 111-149, https://doi.org/10.1146/annurev.earth.32.082503.144359, 2004.

Pindsoo, K. and Soomere, T.: Contribution of wave set-up into the total water level in the Tallinn area, Proc. Estonian Acad. Sci., 64, 338-348, https://doi.org/10.3176/proc.2015.3S.03, 2015.

Pindsoo, K. and Soomere, T.: Basin-wide variations in trends in water level maxima in the Baltic Sea, Cont. Shelf Res., 193, 104029, https://doi.org/10.1016/j.csr.2019.104029, 2020.

Plag, H.-P. and Jüttner, H.-U.: Inversion of the global tide gauge data for present-day ice load changes, Mem. Natl Inst. Polar Res., 54, 301-317, 2001.

Pranzini, E. and Williams, A. (Eds.): Coastal Erosion and Protection in Europe, Taylor and Francis, Hoboken, 483 pp., 2013.

Pugh, D. and Woodworth, P.: Sea-Level Science, Cambridge University Press, Cambridge, 2014.

Quartly, G. D., Legeais, J.-F., Ablain, M., Zawadzki, L., Fernandes, M. J., Rudenko, S., Carrère, L., García, P. N., Cipollini, P., Andersen, O. B., Poisson, J.-C., Mbajon Njiche, S., Cazenave, A., and Benveniste, J.: A new phase in the production of qualitycontrolled sea level data, Earth Syst. Sci. Data, 9, 557-572, https://doi.org/10.5194/essd-9-557-2017, 2017.

Räisänen, J.: Future Climate Change in the Baltic Sea Region and Environmental Impacts, 1, Oxford University Press, Oxford, 2017.

Reusch, T. B. H., Dierking, J., Andersson, H. C., Bonsdorff, E., Carstensen, J., Casini, M., Czajkowski, M., Hasler, B., Hinsby, K., Hyytiäinen, K., Johannesson, K., Jomaa, S., Jormalainen, V., Kuosa, H., Kurland, S., Laikre, L., MacKenzie, B. R., Margonski, P., Melzner, F., Oesterwind, D., Ojaveer, H., Refsgaard, J. C., Sandström, A., Schwarz, G., Tonderski, K., Winder, M., and Zandersen, M.: The Baltic Sea as a time machine for the future coastal ocean, Sci. Adv., 4, eaar8195, https://doi.org/10.1126/sciadv.aar8195, 2018.

Ribeiro, A., Barbosa, S. M., Scotto, M. G., and Donner, R. V.: Changes in extreme sea-levels in the Baltic Sea, Tellus A, 66, 20921, https://doi.org/10.3402/tellusa.v66.20921, 2014.

Richter, A., Groh, A., and Dietrich, R.: Geodetic observation of sea-level change and crustal deformation in the Baltic Sea region, Phys. Chem. Earth Pt. A/B/C, 53-54, 43-53, https://doi.org/10.1016/j.pce.2011.04.011, 2012.

Rosentau, I., Muru, M., Gauk, M., Oja, T., Liibusk, A., Kall, T., Karro, E., Roose, A., Sepp, M., Tammepuu, A., Tross, J., and Up- 
pin, M.: Sea-Level Change and Flood Risks at Estonian Coastal Zone, in: Coastline Changes of the Baltic Sea from South to East, 19, edited by: Harff, J., Furmańczyk, K., and von Storch, H., Springer International Publishing, Cham, 363-388, 2017.

Rutgersson, A., Jaagus, J., Schenk, F., and Stendel, M.: Observed changes and variability of atmospheric parameters in the Baltic Sea region during the last 200 years, Clim. Res., 61, 177-190, https://doi.org/10.3354/cr01244, 2014.

Ryabchuk, D., Kolesov, A., Chubarenko, B., Spiridonov, M., Kurennoy, D., and Soomere, T.: Coastal erosion processes in the eastern Gulf of Finland and their links with geological and hydrometeorological factors, Boreal Environ. Res., 16, 117-137, 2011 a.

Ryabchuk, D., Leont'yev, I., Sergeev, A., Nesterova, E., Sukhacheva, L., and Zhamoida, V.: The morphology of sand spits and the genesis of longshore sand waves on the coast of the eastern Gulf of Finland, Baltica, 24, 13-24, 2011 b.

Ryabchuk, D., Sergeev, A., Burnashev, E., Khorikov, V., Neevin, I., Kovaleva, O., Budanov, L., Zhamoida, V., and Danchenkov, A.: Coastal processes in the Russian Baltic (eastern Gulf of Finland and Kaliningrad area), Q. J. Eng. Geol. Hydrogeol., 28, qjegh2020-036, https://doi.org/10.1144/qjegh2020-036, 2020.

Samuelsson, M. and Stigebrandt, A.: Main characteristics of the long-term sea level variability in the Baltic sea, Tellus A, 48, 672-683, https://doi.org/10.1034/j.1600-0870.1996.t01-400006.x, 1996.

Särkkä, J., Kahma, K. K., Kämäräinen, M., Johansson, M. M., and Saku, S.: Simulated extreme sea levels at Helsinki, Boreal Environ. Res., 22, 299-355, 2017.

Sayin, E. and Krauss, W.: A numerical study of the water exchange through the Danish Straits, Tellus A, 48, 324-341, https://doi.org/10.3402/tellusa.v48i2.12063, 1996.

Schaper, J., Ulm, M., Arns, A., Jensen, J., Ratter, B. M. W., and Weisse, R.: Transdisziplinäres Risikomanagement im Umgang mit extremen Nordsee-Sturmfluten: Vom Modell zur Wissenschafts-Praxis-Kooperation, Küste, 87, 75-114, https://doi.org/10.18171/1.087112, 2019.

Schmager, G., Fröhle, P., Schrader, D., Weisse, R., and MüllerNavarra, S.: Sea State, Tides, Wiley-Blackwell, 143 pp., https://doi.org/10.1002/9780470283134.ch7, 2008.

Schöne, T., Schön, N., and Thaller, D.: IGS Tide Gauge Benchmark Monitoring Pilot Project (TIGA): Scientific benefits, J. Geod., 83, 249-261, https://doi.org/10.1007/s00190-008-0269-y, 2009.

Schöne, T., Esselborn, S., Rudenko, S., and Raimondo, J.-C.: Radar altimetry derived sea level anomalies - The benefit of new orbits and harmonization, in: System earth via geodetic-geophysical space techniques, edited by: Flechtner, F. M., Gruber, T., Güntner, A., Mandea, M., Rothacher, M., Schöne, T., and Wickert, J., Springer, Berlin, Heidelberg, 317-324, 2010.

Schöne, T., Illigner, J., Manurung, P., Subarya, C., Khafid, Zech, C., and Galas, R.: GPS-controlled tide gauges in Indonesia - a German contribution to Indonesia's Tsunami Early Warning System, Nat. Hazards Earth Syst. Sci., 11, 731-740, https://doi.org/10.5194/nhess-11-731-2011, 2011.

Schwabe, J., Ågren, J., Liebsch, G., Westfeld, P., Hammarklint, T., Monoen, J., and Andersen, O. B.: The Baltic Sea Chart Datum 2000 (BSCD2000) Implementation of a common reference level in the Baltic Sea, International Hydrographic Review, International Hydrographic Organization, Monaco, 63-83, 2020.
Sergeev, A., Ryabchuk, D., Zhamoida, V., Leont'yev, I., Kolesov, A., Kovaleva, O., and Orviku, K.: Coastal dynamics of the eastern Gulf of Finland, the Baltic Sea: Toward a quantitative assessment, Baltica, 31, 49-62, https://doi.org/10.5200/baltica.2018.31.05, 2018.

Smith, D. M., Eade, R., Scaife, A. A., Caron, L.-P., Danabasoglu, G., DelSole, T. M., Delworth, T., Doblas-Reyes, F. J., Dunstone, N. J., Hermanson, L., Kharin, V., Kimoto, M., Merryfield, W. J., Mochizuki, T., Müller, W. A., Pohlmann, H., Yeager, S., and Yang, X.: Robust skill of decadal climate predictions, npj Clim. Atmos. Sci., 2, 1366, https://doi.org/10.1038/s41612-019-0071y, 2019.

Soomere, T. and Eelsalu, M.: On the wave energy potential along the eastern Baltic Sea coast, Renew. Energy, 71, 221-233, https://doi.org/10.1016/j.renene.2014.05.025, 2014.

Soomere, T. and Healy, T.: On the dynamics of "almost equilibrium" beaches in semi-sheltered bays along the southern coast of the Gulf of Finland, in: The Baltic Sea Basin, Central and Eastern European Development Studies (CEEDES), edited by: Harff, J., Björck, S., and Hoth, P., Springer-Verlag, Berlin, Heidelberg, 255-279, 2011.

Soomere, T. and Viška, M.: Simulated wave-driven sediment transport along the eastern coast of the Baltic Sea, J. Mar. Syst., 129, 96-105, https://doi.org/10.1016/j.jmarsys.2013.02.001, 2014.

Soomere, T., Kask, A., Kask, J., and Nerman, R.: Transport and distribution of bottom sediments at Pirita Beach, Estonian J. Earth Sci., 56, 233-254, https://doi.org/10.3176/earth.2007.04, 2007.

Soomere, T., Behrens, A., Tuomi, L., and Nielsen, J. W.: Wave conditions in the Baltic Proper and in the Gulf of Finland during windstorm Gudrun, Nat. Hazards Earth Syst. Sci., 8, 37-46, https://doi.org/10.5194/nhess-8-37-2008, 2008.

Soomere, T., Parnell, K. E., and Didenkulova, I.: Implications of fast-ferry wakes for semi-sheltered beaches: a case study at Aegna Island, Baltic Sea, J. Coast. Res., 56, 128-132, 2009.

Soomere, T., Weisse, R., and Behrens, A.: Wave climate in the Arkona Basin, the Baltic Sea, Ocean Sci., 8, 287-300, https://doi.org/10.5194/os-8-287-2012, 2012.

Soomere, T., Pindsoo, K., Bishop, S. R., Käärd, A., and Valdmann, A.: Mapping wave set-up near a complex geometric urban coastline, Nat. Hazards Earth Syst. Sci., 13, 3049-3061, https://doi.org/10.5194/nhess-13-3049-2013, 2013.

Soomere, T., Eelsalu, M., Kurkin, A., and Rybin, A.: Separation of the Baltic Sea water level into daily and multi-weekly components, Cont. Shelf Res., 103, 23-32, https://doi.org/10.1016/j.csr.2015.04.018, 2015.

Soomere, T. and Pindsoo, K.: Spatial variability in the trends in extreme storm surges and weekly-scale high water levels in the eastern Baltic Sea, Cont. Shelf Res., 115, 53-64, https://doi.org/10.1016/j.csr.2015.12.016, 2016.

Soomere, T., Männikus, R., Pindsoo, K., Kudryavtseva, N., and Eelsalu, M.: Modification of closure depths by synchronisation of severe seas and high water levels, Geo-Mar. Lett., 37, 35-46, https://doi.org/10.1007/s00367-016-0471-5, 2017a.

Soomere, T., Viska, M., and Pindsoo, K.: Retrieving the signal of climate change from numerically simulated sediment transport along the eastern Baltic Sea coast, in: Coastline Changes of the Baltic Sea from South to East, 19, edited by: Harff, J., Furmańczyk, K., and von Storch, H., Springer International Publishing, Cham, 327-362, $2017 \mathrm{~b}$. 
Soomere, T., Eelsalu, M., and Pindsoo, K.: Variations in parameters of extreme value distributions of water level along the eastern Baltic Sea coast, Estuarine, Coast. Shelf Sci., 215, 59-68, https://doi.org/10.1016/j.ecss.2018.10.010, 2018.

Soomere, T., Pindsoo, K., Kudryavtseva, N., and Eelsalu, M.: Variability of distributions of wave set-up heights along a shoreline with complicated geometry, Ocean Sci., 16, 1047-1065, https://doi.org/10.5194/os-16-1047-2020, 2020.

Spada, G., Olivieri, M., and Galassi, G.: Anomalous secular sealevel acceleration in the Baltic Sea caused by isostatic adjustment, Ann. Geophys., 57, S0432, https://doi.org/10.4401/ag6548, 2014.

Stammer, D., Wal, R. S. W., Nicholls, R. J., Church, J. A., Le Cozannet, G., Lowe, J. A., Horton, B. P., White, K., Behar, D., and Hinkel, J.: Framework for High-End Estimates of Sea Level Rise for Stakeholder Applications, Earth's Future, 7, 923-938, https://doi.org/10.1029/2019EF001163, 2019.

Stigebrandt, A.: A Model for the Exchange of Water and Salt Between the Baltic and the Skagerrak, J. Phys. Oceanogr., 13, 411-427, https://doi.org/10.1175/15200485(1983)013<0411:AMFTEO>2.0.CO;2, 1983.

Stramska, M. and Chudziak, N.: Recent multiyear trends in the Baltic Sea level, Oceanologia, 55, 319-337, https://doi.org/10.5697/oc.55-2.319, 2013.

Suursaar, Ü. and Sooäär, J.: Decadal variations in mean and extreme sea level values along the Estonian coast of the Baltic Sea, Tellus A, 59, 249-260, https://doi.org/10.1111/j.16000870.2006.00220.x, 2016.

Suursaar, Ü., Kullas, T., Otsmann, M., and Kõuts, T.: A model for storm surge forecasts in the Eastern Baltic Sea, in: Risk analysis III: [papers presented at the Third International Conference on Computer Simulation in Risk Analysis and Hazard Mitigation (RISK/2002) held in Sintra, Portugal in June 2002], WIT transactions on modelling and simulation, 31, edited by: Brebbia, C. A., WIT Press, Southampton, 509-519, 2002.

Suursaar, Ü., Jaagus, J., and Kullas, T.: Past and future changes in sea level near the Estonian coast in relation to changes in wind climate, Boreal Environ. Res., 11, 123-142, 2006 a.

Suursaar, Ü., Kullas, T., Otsmann, M., Saaremäe, I., Kuik, J., and Merilain, M.: Cyclone Gudrun in January 2005 and modelling its hydrodynamic consequences in Estonian coastal waters, Boreal Environ. Res., 11, 143-159, 2006b.

Suursaar, Ü., Kullas, T., and Aps, R.: Currents and waves in the northern Gulf of Riga: Measurement and long-term hindcast, Oceanologia, 54, 421-447, https://doi.org/10.5697/oc.54-3.421, 2012.

Svansson, A.: Exchange of water and salt in the Baltic and adjacent seas, Oceanol. Acta, 3, 431-440, 1980.

Thejll, P., Boberg, F., Schmith, T., Christiansen, B., Christensen, O. B., Madsen, M. S., Su, J., Andree, E., Olsen, S., Langen, P. L., and Madsen, K. S.: Methods used in the Danish Climate Atlas, DMI Rep., DMI, Copenhagen., 19-17, 2020.

Tiepold, L. and Schuhmacher, W.: Historische bis rezente Küstenveränderungen im Raum Fischland-Darß-Zingst-Hiddensee anhand von Kartne, Luft- und Satellitenbildern, Küste, 61, 29-54, 1999.

Tõnisson, H., Orviku, K., Lapinskis, J., Gulbinskas, S., and Zaromskis, R.: The Baltic States: Estonia, Latvia and Lithuania, in:
Coastal Erosion and Protection in Europe, edited by: Pranzini, E. and Williams, A., Taylor and Francis, Hoboken, 47-81, 2013a.

Tõnisson, H., Suursaar, Ü., Rivis, R., Kont, A., and Orviku, K.: Observation and analysis of coastal changes in the West Estonian Archipelago caused by storm Ulli (Emil) in January 2012, J. Coast. Res., 65, 832-837, https://doi.org/10.2112/SI65-141.1, $2013 b$.

Tuomi, L., Kahma, K. K., and Pettersson, H.: Wave hindcast statistics in the seasonally ice-covered Baltic Sea, Boreal Environ. Res., 16, 451-472, 2011.

Tuomi, L., Kahma, K. K., and Fortelius, C.: Modelling fetch-limited wave growth from an irregular shoreline, J. Mar. Syst., 105-108, 96-105, https://doi.org/10.1016/j.jmarsys.2012.06.004, 2012.

Tuomi, L., Pettersson, H., Fortelius, C., Tikka, K., Björkqvist, J.-V., and Kahma, K. K.: Wave modelling in archipelagos, Coast. Eng., 83, 205-220, https://doi.org/10.1016/j.coastaleng.2013.10.011, 2014.

Ulsts, V.: Latvian Coastal Zone of the Baltic Sea, State Geological Survey of Latvia, Riga, 96 pp., 1998.

UNEP: Sand and sustainability: Finding new solutions for environmental governance of global sand resources synthesis for policy makers, vol. 35, United Nations Environment Programme, Nairobi, Kenya, 2019.

Veng, T. and Andersen, O. B.: Consolidating sea level acceleration estimates from satellite altimetry, Adv. Space Res., 68, 496-503, https://doi.org/10.1016/j.asr.2020.01.016, 2020.

Vestøl, O., Ågren, J., Steffen, H., Kierulf, H., and Tarasov, L.: NKG2016LU: A new land uplift model for Fennoscandia and the Baltic Region, J. Geod., 93, 1759-1779, https://doi.org/10.1007/s00190-019-01280-8, 2019.

Viška, M. and Soomere, T.: Hindcast of sediment flow along the Curonian Spit under different wave climates, in: 2012 IEEE/OES Baltic International Symposium (BALTIC), 8-10 May 2012, Klaipeda, 1-7, 2012.

Viška, M. and Soomere, T.: Simulated and observed reversals of wave-driven alongshore sediment transport at the eastern Baltic Sea coast, Baltica, 26, 145-156, https://doi.org/10.5200/baltica.2013.26.15, 2013.

Vitousek, S., Barnard, P. L., and Limber, P.: Can beaches survive climate change?, J. Geophys. Res.-Earth, 122, 1060-1067, https://doi.org/10.1002/2017JF004308, 2017.

Vousdoukas, M. I., Voukouvalas, E., Annunziato, A., Giardino, A., and Feyen, L.: Projections of extreme storm surge levels along Europe, Clim. Dynam., 47, 3171-3190, https://doi.org/10.1007/s00382-016-3019-5, 2016.

Vousdoukas, M. I., Ranasinghe, R., Mentaschi, L., Plomaritis, T. A., Athanasiou, P., Luijendijk, A., and Feyen, L.: Sandy coastlines under threat of erosion, Nat. Clim. Change, 10, 260-263, https://doi.org/10.1038/s41558-020-0697-0, 2020.

Weidemann, H.: Klimatologie der Ostseewasserstände: Eine Rekonstruktion von 1948 bis 2011, Universität Hamburg, Hamburg, 2014.

Weisse, R. and Hünicke, B.: Baltic Sea Level: Past, Present, and Future, in: Oxford Research Encyclopedia of Climate Science, Oxford University Press, Oxford, 2019.

Weisse, R. and Weidemann, H.: Baltic Sea extreme sea levels 19482011: Contributions from atmospheric forcing, Procedia IUTAM, 25, 65-69, https://doi.org/10.1016/j.piutam.2017.09.010, 2017. 
Weisse, R., von Storch, H., Callies, U., Chrastansky, A., Feser, F., Grabemann, I., Günther, H., Winterfeldt, J., Woth, K., Pluess, A., Stoye, T., and Tellkamp, J.: Regional MeteorologicalMarine Reanalyses and Climate Change Projections: Results for Northern Europe and Potential for Coastal and Offshore Applications, B. Am. Meteorol. Soc., 90, 849-860, https://doi.org/10.1175/2008BAMS2713.1, 2009.

Weisse, R., Bisling, P., Gaslikova, L., Geyer, B., Groll, N., Hortamani, M., Matthias, V., Maneke, M., Meinke, I., Meyer, E. M. I., Schwichtenberg, F., Stempinski, F., Wiese, F., and WöcknerKluwe, K.: Climate services for marine applications in $\mathrm{Eu}-$ rope, Earth Perspect., 2, 3887, https://doi.org/10.1186/s40322015-0029-0, 2015.

Weisse, R., Grabemann, I., Gaslikova, L., Meyer, E., Tinz, B., Fery, N., Möller, T., Rudolph, E., Brodhagen, T., Arns, A., Jensen, J., Ulm, M., Ratter, B., and Schaper, J.: Extreme Nordseesturmfluten und mögliche Auswirkungen: Das EXTREMENESS Projekt, Küste, 87, 39-45, https://doi.org/10.18171/1.087110, 2019.

Winsor, P., Rodhe, J., and Omstedt, A.: Baltic Sea ocean climate: An analysis of $100 \mathrm{yr}$ of hydrographic data with focus on the freshwater budget, Clim. Res., 18, 5-15, https://doi.org/10.3354/cr018005, 2001.

Witting, R.: Tidevatten i østerjönoch Finska, Fennia, 29, 1-84, 1911.

Wolski, T. and Wiśniewski, B.: Geographical diversity in the occurrence of extreme sea levels on the coasts of the Baltic Sea, J. Sea Res., 159, 101890, https://doi.org/10.1016/j.seares.2020.101890, 2020.

Wolski, T., Wiśniewski, B., Giza, A., Kowalewska-Kalkowska, H., Boman, H., Grabbi-Kaiv, S., Hammarklint, T., Holfort, J., and Lydeikaite, Ž.: Extreme sea levels at selected stations on the Baltic Sea coast, Oceanologia, 56, 259-290, https://doi.org/10.5697/oc.56-2.259, 2014.

Woolf, D. K., Shaw, A. G. P., and Tsimplis, M. N.: The influence of the North Atlantic Oscillation on sea-level variability in the North Atlantic region, J. Atmos. Ocean Sci., 9, 145-167, https://doi.org/10.1080/10236730310001633803, 2003.

Wübber, C. and Krauss, W.: The Two dimensional seiches of the baltic sea, Oceanol. Acta, 2, 435-446, 1979.
Zappa, G. and Shepherd, T. G.: Storylines of Atmospheric Circulation Change for European Regional Climate Impact Assessment, J. Climate, 30, 6561-6577, https://doi.org/10.1175/JCLI-D-160807.1, 2017.

Zhang, W., Harff, J., and Schneider, R.: Analysis of 50-year wind data of the southern Baltic Sea for modelling coastal morphological evolution - a case study from the Darss-Zingst Peninsula, Oceanologia, 53, 489-518, https://doi.org/10.5697/oc.53-1TI.489, 2011a.

Zhang, W., Harff, J., Schneider, R., and Wu, C.: Development of a modelling methodology for simulation of long-term morphological evolution of the southern Baltic coast, Ocean Dynam., 60, 1085-1114, https://doi.org/10.1007/s10236-010-0311-5, 2010.

Zhang, W., Harff, J., Schneider, R., Meyer, M., and Wu, C.: A Multiscale Centennial Morphodynamic Model for the Southern Baltic Coast, J. Coast. Res., 276, 890-917, https://doi.org/10.2112/JCOASTRES-D-10-00055.1, $2011 \mathrm{~b}$.

Zhang, W., Harff, J., Schneider, R., Meyer, M., Zorita, E., and Hünicke, B.: Holocene morphogenesis at the southern Baltic Sea: Simulation of multi-scale processes and their interactions for the Darss-Zingst peninsula, J. Mar. Syst., 129, 4-18, https://doi.org/10.1016/j.jmarsys.2013.06.003, 2014.

Zhang, W., Schneider, R., Kolb, J., Teichmann, T., DudzinskaNowak, J., Harff, J., and Hanebuth, T. J. J.: Land-sea interaction and morphogenesis of coastal foredunes - A modeling case study from the southern Baltic Sea coast, Coast. Eng., 99, 148166, https://doi.org/10.1016/j.coastaleng.2015.03.005, 2015.

Zhang, W., Schneider, R., Harff, J., Hünicke, B., and Fröhle, P.: Modelling of Medium-Term (Decadal) Coastal Foredune Morphodynamics-Historical Hindcast and Future Scenarios of the Świna Gate Barrier Coast (Southern Baltic Sea), in: Coastline Changes of the Baltic Sea from South to East, 19, edited by: Harff, J., Furmańczyk, K., and von Storch, H., Springer International Publishing, Cham, 112-140, 2017.

Zhang, Z.-H. and Leppäranta, M.: Modeling the influence of ice on sea level variations in the Baltic Sea, Geophysica, 31, 31-45, 1995. 